\title{
Rzeźbiarka Piłsudskiego Związki Olgi Niewskiej z Bydgoszczą
}

\author{
ANNA NADOLSKA \\ Uniwersytet Kazimierza Wielkiego w Bydgoszczy \\ Muzeum Okręgowe im. Leona Wyczółkowskiego w Bydgoszczy \\ e-mail: anna.nadolska@muzeum.bydgoszcz.pl \\ ORCID: 0000-0002-4063-7431
}

Keywords: Olga Newska, sculptor, City Museum, women's art exhibition, Józef Piłsudski monument, interwar period, Bydgoszcz

Słowa klucze: Olga Niewska, rzeźbiarka, Muzeum Miejskie, wystawa sztuki kobiet, pomnik Józefa Piłsudskiego, okres międzywojenny, Bydgoszcz

\begin{abstract}
Pitsudski's Sculptor. Olga Niewska Relationships with Bydgoszcz

Olga Newska, a sculptor from Warsaw, at the beginning of 30. of XX century, was associated with the city on the Brda river. During this period residents of Bydgoszcz were introduced to the art of this famous artist. In 1930 Newska took part in the 1st Exhibition of Polish Women Artists organized by City Museum in Bydgoszcz and more than one year later Józef Piłsudski monument created by this artist was revealed in Bydgoszcz. This article describes Bydgoszcz episodes of the art life of Olga Newska.
\end{abstract}

\begin{abstract}
Abstrakt
Na początku lat trzydziestych XX w. z miastem nad Brdą związana była warszawska rzeźbiarka Olga Niewska. Bydgoszczanie mieli wówczas okazję zapoznania się z reprezentatywnymi dziełami tej znakomitej i wpływowej artystki. W 1930 r. Niewska wzięła udział w I Wystawie Artystek Polskich zorganizowanej przez bydgoskie Muzeum
\end{abstract}


Miejskie, a półtora roku później w mieście nad Brdą stanął rzeźbiarski portret marszałka Józefa Piłsudskiego jej autorstwa. Celem niniejszego artykułu jest przybliżenie bydgoskich epizodów w życiorysie twórczym Olgi Niewskiej.

Bydgoszcz w okresie międzywojennym gościła wiele osób związanych z ogólnopolskim życiem kulturalnym. Wśród postaci legitymujących się znanym nazwiskiem byli malarze, rzeźbiarze, graficy, literaci, reżyserzy, aktorzy, śpiewacy operowi, kompozytorzy, muzycy. Na rozwój kulturalny miasta nad Brdą nie miało zatem wpływu jedynie lokalne środowisko literackie i artystyczne, ale także często wybitne jednostki twórcze spoza Bydgoszczy. Do tej ostatniej grupy należeli między innymi Leon Wyczółkowski, Konstanty Laszczka, Józef Weyssenhoff, Adam Grzymała-Siedlecki, Wanda Siemaszkowa, Ada Sari oraz Karol Szymanowski ${ }^{1}$. Na początku lat trzydziestych XX wieku z miastem nad Brdą związała się także warszawska rzeźbiarka Olga Niewska. Bydgoszczanie mieli wówczas okazję poznania reprezentatywnych prac tej znakomitej i wpływowej artystki wystawionych w Muzeum Miejskim, ponadto dzieło rzeźbiarki stanęło przed jednym z ważniejszych budynków wojskowych w Bydgoszczy. W niniejszym tekście, obok zarysu biografii Niewskiej, omówione zostaną także bydgoskie epizody w życiorysie twórczym autorki rzeźb marszałka Józefa Piłsudskiego.

\section{Zarys biografii artystycznej}

Olga Niewska (il. 1) urodziła się 28 maja 1898 roku w Charkowie na Ukrainie jako córka Jana Niewskiego - architekta i budowniczego oraz Eugenii z Dellavosów (Della Vosów) - malarki amatorki pochodzącej z osiadłej w Rosji hiszpańskiej rodziny². W Kijowie uczyła się w szkole realnej, a następnie

1 Zdzisław Mrozek, „Polska kultura i sztuka w Bydgoszczy w latach 1920-1939”, w Historia Bydgoszczy, t. 2, cz. 1 1920-1939, red. Marian Biskup (Bydgoszcz: Bydgoskie Towarzystwo Naukowe, 1999), 719-781.

2 Muzeum Narodowe w Warszawie (dalej: MNW), Zbiory Ikonograficzne i Fotograficzne, rkps 2193/1-3, Życiorys Olgi Niewskiej - rękopis; Joanna Daranowska-Łukaszewska, „Szczekowska Olga”, w Polski słownik biograficzny, t. 47 (Szaniawski Józef - Szeliga Franciszek), red. Andrzej Romanowski (Warszawa-Kraków: Wydawnictwo Towarzystwa Naukowego Societas Vistulana, 2010-2011), 247; Hanna Kubaszewska i Wojciech Przybyszewski, „Niewska Olga”, w Słownik artystów polskich i obcych w Polsce działających (zmarłych przed 1966 r.). Malarze, rzeźbiarze, graficy, t. $6 \mathrm{~N}-P c$, red. Katarzyna Mikocka-Rachubowa i Małgorzata Biernacka (Warszawa: Instytut Sztuki PAN, 1998), 84; Wojciech Przybyszewski, Olga Niewska. Piękno 
w szkole malarskiej. W 1919 roku, tuż po odzyskaniu przez Polskę niepodległości, rozpoczęła studia rzeźbiarskie w krakowskiej Akademii Sztuk Pięknych w pracowni Konstantego Laszczki ${ }^{3}$. Pod koniec 1920 roku swoje gipsowe rzeźby Satyr myśliciel, Demon i Portret Feliksa Jasieńskiego pokazała na wystawie w Towarzystwie Przyjaciół Sztuk Pięknych w Krakowie i uzyskała przychylne recenzje 4 , a w lutym 1922 roku w tym samym Towarzystwie odbyła się jej pierwsza indywidualna wystawa 5 . Twórczość Niewskiej pozostawała w tym czasie pod wyraźnym wpływem Konstantego Laszczki i Xawerego Dunikowskiego $^{6}$. W 1922 roku uzyskała nagrodę Polskiej Akademii Umiejętności ${ }^{7}$, rok później ukończyła studia i otworzyła pracownię artystyczną przy ul. Zakroczymskiej w Warszawie ${ }^{8}$. W latach 1926-1928 studiowała w Paryżu, gdzie kształciła się pod kierunkiem Émile’a Antoine’a Bourdelle’a9.

Niewska miała dwie wystawy indywidualne i wzięła udział w trzydziestu dwóch wystawach zbiorowych. Swoje prace pokazywała na krajowych ekspozycjach zorganizowanych przez Towarzystwo Zachęty Sztuk Pięknych w Warszawie, Związek Zawodowy Polskich Artystów Plastyków oraz Instytut Propagandy Sztuki w Warszawie, natomiast za granicą na IX wystawie olimpijskiej w Amsterdamie w 1928 roku, X wystawie olimpijskiej w Los Angeles w 1932 roku, na Wystawie Światowej w Brukseli w 1935 roku, XI wystawie olimpijskiej w Berlinie w 1936 roku, Wystawie Międzynarodowej „Sztuka i Technika” w Paryżu w 1937 roku (gdzie otrzymała złoty medal za rzeźbę

za kurtyna zapomnienia (Poznań: Dom Wydawniczy Rebis, 2001), 37; Rzeźba Olgi Niewskiej. Katalog wystawy, oprac. Krystyna Mart (Chełm: Muzeum Chełmskie, czerwiec-październik 2000), 5; Hanna Kotkowska-Bareja, „Olga Niewska”, w Artystki polskie. Katalog wystawy (Warszawa: Muzeum Narodowe w Warszawie, 1991), 259; zob. też Izabela Mościcka, „Trzy gracje polskiej rzeźby art. déco: Gross, Mickun, Niewska”, w Polskie art déco: Materiały piątej sesji naukowej „Polskie art déco. Rzeźba i płaskorzeźba” pod przewodnictwem prof. Ireny Huml, prof. Anny Sieradzkiej i prof. Andrzeja K. Olszewskiego w Muzeum Mazowieckim w Płocku 22-23 kwietnia 2013 roku, red. Zbigniew Chlewiński (Płock: Muzeum Mazowieckie, 2015), 129-141.

3 Daranowska-Łukaszewska, „Szczekowska Olga”, 247; Kubaszewska i Przybyszewski, „Niewska Olga”, 84; Przybyszewski, Olga Niewska, 39-42; por. Paweł Freus, „Olga Niewska”, CULTURE.PL Twórcy, Dostęp 16 czerwca 2018, http://culture.pl/pl/tworca/olga-niewska.

4 Daranowska-Łukaszewska, „Szczekowska Olga”, 247; Przybyszewski, Olga Niewska, 233.

Przybyszewski, Olga Niewska, 234.

6 Daranowska-Łukaszewska, „Szczekowska Olga”, 247; Przybyszewski, Olga Niewska, 48-49.

Daranowska-Łukaszewska, „Szczekowska Olga”, 247; Przybyszewski, Olga Niewska, 55.

Daranowska-Łukaszewska, „Szczekowska Olga”, 247; Przybyszewski, Olga Niewska, 64.

MNW, Zbiory Ikonograficzne i Fotograficzne, rkps 2193/1-3, Życiorys Olgi Niewskiej - rękopis; Daranowska-Łukaszewska, „Szczekowska Olga”, 247; Kubaszewska i Przybyszewski, „Niewska Olga”, 84; Przybyszewski, Olga Niewska, 74. 
Pelikan) oraz Międzynarodowej Wystawie w Nowym Jorku w 1939 roku $^{10}$. Należała do najciekawszych polskich rzeźbiarek okresu międzywojennego. W jej pracach daje się zauważyć twórcze wykorzystanie elementów różnorodnych kierunków i tendencji. Szybko zyskała popularność i uznanie zarówno krytyki, jak i odbiorców ${ }^{11}$.

Bogatą twórczość Olgi Niewskiej, charakteryzującą się zróżnicowaniem tematycznym i stylistycznym, można zaliczyć do nurtu realistycznego. Początkowo w pracach rzeźbiarki widoczny jest wpływ jej profesorów, natomiast w dojrzalszych dziełach ujawniają się cechy nowego klasycyzmu i ,upraszczająca formy stylizacja i dekoracyjność bliska estetyce 'Rytmu' "12. Sztuka uprawiana przez stowarzyszenie „Rytm” była - zgodnie z opinią Aleksandry Melbechowskiej-Luty - „umiarkowanie nowoczesna, reprezentacyjna, elegancka, czytelna, komunikatywna, 'estetyczna', harmonijna, zdyscyplinowana, dekoracyjna, zachęcająco ozdobna, a nadto w znacznym stopniu rodzima, własna”"13.

Ogromną część dorobku Niewskiej stanowią rzeźbione portrety wielu znanych osobistości ze świata polityki, wojska i kultury Drugiej Rzeczypospolitej. Artystce pozowali między innymi Józef Piłsudski, Ignacy Mościcki, Ignacy Daszyński, Walery Sławek, generał Aleksander Litwinowicz, gen. Gustaw Orlicz-Dreszer, major Kazimierz Kubala, Zula Pogorzelska, Mieczysława Ćwiklińska, Halina Szmolcówna, Tadeusz Żuk-Skarszewski ${ }^{14}$. Do najlepszych jej prac portretowych należą Portret Stefana Jaracza z maską oraz Portret Walasiewiczówny ${ }^{15}$. Niewska tworzyła ponadto portrety istot mitycznych, personifikacje pewnych pojęć, popiersia anonimowych osób - mieszczą się w tym

10 Daranowska-Łukaszewska, „Szczekowska Olga”, 247-250; Kubaszewska i Przybyszewski, „Niewska Olga”, 84-87; Rzeźba Olgi Niewskiej. Katalog, 16-21; Kotkowska-Bareja, „Olga Niewska”, 259; zob. też Zbigniew Porada, „Polskie artystki w Olimpijskich Konkursach Sztuki i Literatury 1928-1948”, Prace Naukowe Akademii im. Jana Długosza w Częstochowie. Kultura Fizyczna 16, nr 4 (2017): 30-31, 44-45; szerzej Przybyszewski, Olga Niewska, 233-239.

11 Aleksandra Melbechowska-Luty, Posagi i ludzie. Rzeźba polska dwudziestolecia międzywojennego (1918-1939) (Warszawa: Wydawnictwo Neriton, 2005), 235, 246.

12 Kotkowska-Bareja, „Olga Niewska”, 259; szerzej Rzeźba Olgi Niewskiej. Katalog; Joanna Daranowska-Łukaszewska, „Szczekowska (Niewska-Szczekowska) 1. v. Zbiza, 2. v. Maderowa, Olga (1898-1943), rzeźbiarka”, Dostęp 18 grudnia 2017, www.ipsb.nina.gov.pl/a/biografia/ olga-szczekowska.

13 Melbechowska-Luty, Posagi i ludzie, 115, 247-248.

14 Daranowska-Łukaszewska, „Szczekowska Olga”, 249; Kubaszewska i Przybyszewski, „Niewska Olga”, 85; Przybyszewski, Olga Niewska, 67-71, 77-85, 118, 122-126, 227, 232; Rzeźba Olgi Niewskiej. Katalog, 11-12; Melbechowska-Luty, Posąi i ludzie, 246.

15 Przybyszewski, Olga Niewska, 148, 160-161; zob. też Katarzyna Balutowska, „Emancypacja kobiet w sztuce Olgi Niewskiej”, Dostęp 16 czerwca 2018, https://www.polishmuseumofamerica.org/emancypacja-kobiet-w-sztuce-olgi-niewskiej/. 
kręgu na przykład Satyr, Grzech, Niewolnik, Głowa mężczyzny, Popiersie kobiety, Rzeźba pani ${ }^{16}$. Rzeźbiła również akty kobiece - takie jak Kąpiąca się, Przebudzenie i Ekstaza tańca (portret tancerki baletowej Haliny Hulanickiej) ${ }^{17}$, figury o tematyce sportowej - tu na przykład Bokser ${ }^{18}$, religijnej - na przykład Święty Jerzy w walce ze smokiem ${ }^{19}$, rzeźby i płaskorzeźby nagrobne - na przykład Portret Ignacego Daszyńskiego ${ }^{20}$, Postać smutku, Chrystus, Anioł ${ }^{21}$, rzeźby animalistyczne - na przykład Pelikan, Królik, Buldog francuski ${ }^{22}$. Aplauz krytyków i publiczności zyskała jej rzeźba sportowa, w tym postaci biegaczy, strzelców, narciarzy, łuczników, pływaków itd. Jak podaje jeden z biografów artystki, Wojciech Przybyszewski, najpierw pokazywane były one w wersji gipsowej na różnych wystawach, dopiero później niektóre z nich zyskały postać brązowych statuetek z przeznaczeniem na nagrody w zawodach sportowych na przykład U mety, Łuczniczka, Strzelec, Łucznik, Lotnik ${ }^{23}$. Sławę Niewskiej zapewniły także przedstawienia „Murzynów” - na przykład Głowa derwisza, Głowa Murzyna, Głowa Murzynki ${ }^{24}$. Artystka wykonywała zarówno dzieła monumentalne, wielkogabarytowe, jak i drobne prace dekoracyjne, $w$ tym figurki (np. Japończyk ${ }^{25}$ ), pieczątki do listów $\left(\right.$ Faun $\left.^{26}\right)$, medaliony, medale i plakiety (np. jednostronny medal Józef Piłsudski ${ }^{27}$ ). Nie stroniła także od projektowania manekinów wystawowych i główek fryzjerskich ${ }^{28}$. Używała różnych materiałów, najważniejsze to glina, gips, beton, kamień, brąz, drewno ${ }^{29}$. Prace

16 Przybyszewski, Olga Niewska, 62-63, 50, 147, 152.

17 Przybyszewski, Olga Niewska, 17-21, 109, 138-139, 232.

18 Przybyszewski, Olga Niewska, 104.

19 Przybyszewski, Olga Niewska, 95, 100.

20 Przybyszewski, Olga Niewska, 40-41.

21 Przybyszewski, Olga Niewska, 114-117.

22 Daranowska-Łukaszewska, „Szczekowska Olga”, 248; Przybyszewski, Olga Niewska, 63, 145, 182-183; Joanna Sosnowska, Poza kanonem. Sztuka polskich artystek 1880-1939 (Warszawa: Instytut Sztuki PAN, 2003), 208.

23 Przybyszewski, Olga Niewska, 91-93; Sosnowska, Poza kanonem, 133-137; Daranowska-Łukaszewska, „Szczekowska Olga”, 248; Kubaszewska i Przybyszewski, „Niewska Olga”, 84.

24 Daranowska-Łukaszewska, „Szczekowska Olga”, 248; Kubaszewska i Przybyszewski, „Niewska Olga”, 85; Przybyszewski, Olga Niewska, 126-133; Melbechowska-Luty, Posagi i ludzie, 246; zob. też Balutowska, „Emancypacja kobiet”.

25 Przybyszewski, Olga Niewska, 23-25.

26 Przybyszewski, Olga Niewska, 63.

27 Przybyszewski, Olga Niewska, 42-143.

28 Daranowska-Łukaszewska, „Szczekowska Olga”, 248; Przybyszewski, Olga Niewska, 140-141.

29 Daranowska-Łukaszewska, „Szczekowska Olga”, 248-249; Melbechowska-Luty, Posagi i ludzie, 246; szerzej Przybyszewski, Olga Niewska; Daranowska-Łukaszewska, „Szczekowska (Niewska-Szczekowska)". 
rzeźbiarki w metalu wytapiano w krakowskiej firmie Leona Dyrka, w warszawskich zakładach rzemieślniczych Braci Łopieńskich, Józefa Wasilewskiego, Leona Krantza (Kranca) i Adama Nagalskiego, natomiast dzieła z betonu powstawały w warszawskiej pracowni rzeźbiarsko-sztukatorskiej Stanisława Jankowskiego ${ }^{30}$.

Olga Niewska była trzykrotnie zamężna: ze Zbizą (małżeństwo unieważnione $)^{31}$, Henrykiem Maderą i Władysławem Szczekowskim ${ }^{33}$. Nie miała dzie$\mathrm{ci}^{34}$. Zmarła 25 maja 1943 roku w warszawskim szpitalu po odbytej operacji. Została pochowana na stołecznym cmentarzu ewangelicko-augsburskim ${ }^{35}$.

Dzieła Olgi Niewskiej znajdują się w licznych muzeach krajowych oraz muzeum amerykańskim. Pojawiają się także w kolekcjach prywatnych i w krajowym handlu antykwarycznym ${ }^{36}$. Obecnie, po latach zapomnienia i zmarginalizowania w okresie Polski Ludowej, znakomity dorobek artystki jest szeroko omawiany i prezentowany publiczności ${ }^{37}$.

\section{Prace Niewskiej w bydgoskim Muzeum Miejskim}

W niepodległej Polsce nasiliła się, zapoczątkowana u schyłku XIX wieku, tendencja do podejmowania przez kobiety działalności artystycznej, a także do pokazywania przez nie prac na wystawach sztuki kobiet ${ }^{38}$. Prace artystek

30 Daranowska-Łukaszewska, „Szczekowska Olga”, 249; Przybyszewski, Olga Niewska, 52, 142 , 232-233; por. Daranowska-Łukaszewska, „Szczekowska (Niewska-Szczekowska)”.

31 Daranowska-Łukaszewska, „Szczekowska Olga”, 249; Przybyszewski, Olga Niewska, 42, 64.

32 Daranowska-Łukaszewska, „Szczekowska Olga”, 249; Przybyszewski, Olga Niewska, 109.

33 Władysław Szczekowski, ur. w 1898 r., ppłk dypl. artylerii Wojska Polskiego, działał w Armii Krajowej, m.in. w sztabie gen. bryg. Stefana Roweckiego „Grota”, ps. C-7, Leszczyc, Stanisław, Sztark, w 1944 r. zamordowany przez Niemców w nieznanych okolicznościach, zob. Andrzej K. Kunert, „Szczekowski Władysław”, w Polski słownik biograficzny, t. 47 (Szaniawski Józef - Szeliga Franciszek), red. Andrzej Romanowski (Warszawa-Kraków: Wydawnictwo Towarzystwa Naukowego Societas Vistulana, 2010-2011), 250-252; Rzeźba Olgi Niewskiej. Katalog, s. 12; Daranowska-Łukaszewska, „Szczekowska Olga”, 249; szerzej Przybyszewski, Olga Niewska, 105, 111, 179-204.

Daranowska-Łukaszewska, „Szczekowska Olga”, 249; Przybyszewski, Olga Niewska, 14.

35 Daranowska-Łukaszewska, „Szczekowska Olga”, 249; Rzeźba Olgi Niewskiej. Katalog, 12; Przybyszewski, Olga Niewska, 171-178, podaje, że Niewska została pochowana na cmentarzu ewangelicko-reformowanym.

36 Szerzej Daranowska-Łukaszewska, „Szczekowska Olga”, 249; por. Kubaszewska i Przybyszewski, „Niewska Olga”, 85-86.

37 Melbechowska-Luty, Posągi i ludzie, 246.

38 Pierwsze wystawy sztuki kobiet w 1899 r. w Krakowie i Warszawie zorganizowało Stowarzyszenie Artystek Polskich (potem Koło Artystek Polskich). W następnych latach odbyły się kolejne oddzielne wystawy artystek, współczesnych i nieżyjących, w Krakowie, Warsza- 
reprezentujących różne dziedziny sztuki - malarstwo, grafikę, rzeźbę, rzemiosło artystyczne - były już eksponowane w specjalnie wydzielonych dwóch pawilonach kobiecych na Powszechnej Wystawie Krajowej w Poznaniu, która odbyła się w 1929 roku $^{39}$. Do historii przeszła jednak przede wszystkim wystawa zorganizowana w 1939 roku w warszawskiej Resursie Obywatelskiej i zatytułowana „Świat kobiety” ${ }^{40}$.

Muzeum Miejskie w Bydgoszczy ${ }^{41}$, którego pracownicy śledzili trendy obowiązujące zarówno w sztuce polskiej, jak i wystawiennictwie, również podjęło się zaprezentowania prac kobiet. I Wystawa Artystek Polskich została otwarta w niedzielę 26 stycznia 1930 roku. Do udziału w tym przedsięwzięciu bydgoska instytucja kultury zaprosiła artystki, których twórczość - częściowo pokazana rok wcześniej na Powszechnej Wystawie Krajowej - była znana i ceniona w Drugiej Rzeczypospolitej ${ }^{42}$. Ta pierwsza w Bydgoszczy - i w całej zachodniej dzielnicy państwa - wystawa dzieł rodzimych artystek cieszyła

wie i we Lwowie, zob. Agnieszka Morawińska, „Artystki polskie”, w Artystki polskie. Katalog, 13; szerzej Sosnowska, Poza kanonem, 221-231; zob. też „Wystawy sztuki kobiet”, Dostęp 29 czerwca 2018, http://wystawykobiet.amu.edu.pl/wystawy.html. Sosnowska, Poza kanonem, 223-230. Wystawa „Świat kobiety” 25.V.-25.VI.1939 (Warszawa: Wydawnictwo W. Majchert i Syn, 1939); „Wystawa: Świat kobiety”, Dostęp 22 lipca 2018, http://wystawykobiet.amu.edu.pl/ wystawa/swiat-kobiety,46.html. Obecnie Muzeum Okręgowe im. Leona Wyczółkowskiego w Bydgoszczy.

42 Muzeum Okręgowe im. Leona Wyczółkowskiego w Bydgoszczy (dalej: MOB), Wykaz teczek z wystawami, poz. 32, 5, Pierwsza Wystawa Artystek Polskich odbyła się w Muzeum Miejskim w dniach od 26.01. (wernisaż godz. 12:30) do 9.03.1930 r.; MOB, Pierwsza wystawa artystek polskich, teczka 32, Zaproszenie na otwarcie wystawy 26 I 1930; Wystawa artystek polskich, 1930; Zdzisław Hojka, Muzeum w Bydgoszczy 1923-2008. Dzieje i zbiory, t. 1 (Od Kościoła Klarysek po Wyspę Młyńską. Muzeum w Bydgoszczy 1923-2008, red. Michał Woźniak) (Bydgoszcz: Muzeum Okręgowe im. Leona Wyczółkowskiego, 2008), 77, podaje, że przed 1930 r. w bydgoskim muzeum, działającym od 1923 r., indywidualne wystawy artystek urządzono w 1924 r. (Elżbieta Śliwińska-Kapturkiewicz) i w 1928 r. (Anna Römerowa), w 1929 r. w wystawie zbiorowej „Galerja Miejska” uczestniczyły także kobiety; Daranowska-Łukaszewska, „Szczekowska Olga”, 248; Kubaszewska i Przybyszewski, „Niewska Olga”, 84; zob. też „Historia wystaw sztuki kobiet w Polsce”, red. Agata Jakubowska, Sztuka i Dokumentacja 15 (2016); „Wystawa: I Wystawa Artystek Polskich, Wystawy Sztuki Kobiet”, Dostęp 16 czerwca 2018, http://wystawykobiet.amu.edu.pl/wystawa/i-wystawa-artystek-polskich,33.html; „Kronika. Wystawa artystek polskich”, Dziennik Bydgoski, 26 stycznia 1930, 12; „Wystawa artystek polskich”, Gazeta Bydgoska. Kurjer Bydgoski, 26 stycznia 1930, 6; „Wystawa malarek i rzeźbiarek”, Gazeta Bydgoska. Kurjer Bydgoski, 28 stycznia 1930, 5; por. Mrozek, „Polska kultura”, 761-762; Dział Sztuki: Powszechna Wystawa Krajowa (Poznań: Powszechna Wystawa Krajowa, 1929), 10-11, 14, 16-17, 20-21 -artystki uczestniczące w I Wystawie Artystek Polskich w 1930 r. w Muzeum Miejskim rok wcześniej wzięły udział (z wyjątkiem Wandy Gentil-Tipperhauer) w Powszechnej Wystawie Krajowej w Poznaniu. 
się dużym zainteresowaniem miłośników sztuki ${ }^{43}$. Jej prestiżowy charakter potwierdza z kolei chociażby uwzględnienie jej w kalendarium najważniejszych polskich wydarzeń kulturalnych okresu międzywojennego, zamieszczonym w opublikowanym w 1974 roku obszernym opracowaniu Polskie życie artystyczne w latach 1915-1939 pod redakcją Aleksandra Wojciechowskiego ${ }^{44}$.

W bydgoskim muzeum swoje prace wystawiło łącznie dwadzieścia artystek: malarki, rzeźbiarki i graficzka, reprezentując środowiska twórcze Warszawy, Krakowa, Poznania, Wilna i Lwowa. Były wśród nich Wanda Gentil-Tippenhauer i Janina Gessnerówna, które już wcześniej pokazały swoje dzieła w mieście nad Brdą, a także między innymi Anna Berent, Zofia Albinowska-Minkiewiczowa, Alina Czarnowska, Aneri (Irena Weissowa), Kazimiera Pajzderska, Jadwiga Tetmajer-Naimska, Michalina Krzyżanowska, Janina Konarska ${ }^{45}$. Do tej grupy utalentowanych artystycznie kobiet należała też Olga Niewska ${ }^{46}$. Warszawską rzeźbiarkę i dwie inne artystki przybyłe na wernisaż wystawy powitał decernent muzeum, inż. Tadeusz Janicki ${ }^{47}$ (włodarzom oraz przedstawicielom elity intelektualno-kulturalnej Bydgoszczy dobrze znany był mistrz-nauczyciel rzeźbiarki, prof. Konstanty Laszczka autor pomnika Henryka Sienkiewicza odsłoniętego w tym mieście niespełna trzy lata wcześniej ${ }^{48}$. Warto podkreślić, że nazwisko Niewskiej posłużyło do promowania tego przedsięwzięcia ${ }^{49}$ : w opublikowanym katalogu bydgoskiej

43 Początkowo finisaż wystawy zaplanowano na 2 III 1930 r., ale z powodu dużej frekwencji ekspozycję przedłużono do 9 III, MOB, Pierwsza wystawa artystek polskich, teczka 32, Wystawa artystek polskich (malarstwo i rzeźba); Komunikat. Przedłużenie Wystawy artystek polskich, 4 III 1930 r.; Pismo do Redakcji „Dziennika Bydgoskiego” i „Gazety Bydgoskiej”, 14 I $1930 \mathrm{r}$.

44 Polskie życie artystyczne w latach 1915-1939, red. Aleksander Wojciechowski (Wrocław-Warszawa-Kraków-Gdańsk: Ossolineum, 1974), 221.

45 Wanda Gentil-Tippenhauer wystawiała w Bydgoszczy na przełomie 1927/1928 r., Janina Gessner wiosną 1929 r., MOB, Wykaz teczek z wystawami, poz. 32, 4-5; Sosnowska, Poza kanonem, 231; MNW, Zbiory Ikonograficzne i Fotograficzne, rkps 2193/1-3, Życiorys Olgi Niewskiej - rękopis; Katalog I Wystawy Artystek Polskich styczeń-luty 1930 (Bydgoszcz: Muzeum Miejskie, 1930); Artystki polskie. Katalog, 376; „Olga Niewska 1898-1943”, Centrum Rzeźby Polskiej w Orońsku, Dostęp 16 czerwca 2018, www.rzezba-oronsko.pl/index.php?kolekcja_crp,38,174,niewska_olga.

46 Muzeum Miejskie zaprosiło Niewską do udziału w wystawie i przesłania 4-8 prac, zob. MOB, Pierwsza wystawa artystek polskich, teczka 32, Pismo Muzeum Miejskiego do Olgi Niewskiej w Warszawie, 5 XII 1929 r.; Pismo Olgi Niewskiej do Muzeum Miejskiego w Bydgoszczy, 17 XII $1929 \mathrm{r}$.

47 „Wystawa malarek i rzeźbiarek”, 5.

48 Zob. Mrozek, „Polska kultura”, 763-764.

49 MOB, Pierwsza wystawa artystek polskich, teczka 32, Wystawa artystek polskich (malarstwo i rzeźba). 
wystawy sztuki kobiet wśród fotografii poszczególnych prac widnieją również jej dzieła. Zostały one wybrane jako reprezentatywne dla tematów i technik najczęściej przez nią podejmowanych i stosowanych w latach dwudziestych $\mathrm{XX}$ wieku. Obok wielkogabarytowych, gipsowych rzeźb w katalogu wymieniono statuetki i nagrody sportowe $\mathrm{z}$ brązu, ceramiczne figurki oraz medal i plakiety: „Niewska Olga. 75. Łucznik, rzeźba, gips. 76. Przebudzenie, rzeźba, gips. 77. U mety, bronz. 78. Łuczniczka, bronz. 79. Japończyk, porcelana. 80. Piesek, porcelana. 81. Królik, porcelana. 82. Maskotte'a, bronz. 83. Puhar [sic], bronz. 84. Łucznik plakieta, bronz. 85. Husarz, medal, bronz. 86. Piłsudzki [sic], plakieta, bronz"50.

W opublikowanym w „Dzienniku Bydgoskim” obszernym artykule traktującym o pracach Niewskiej wystawionych w Muzeum Miejskim znajdują się ich dość szczegółowe opisy, z wyjątkiem brązowej plakiety przedstawiającej Łucznika ${ }^{51}$.

Dwie gipsowe rzeźby, które można było podziwiać na bydgoskiej ekspozycji, pokazane zostały na wspomnianej już Powszechnej Wystawie Krajowej w Poznaniu w czerwcu 1929 roku - gdzie Przebudzenie (Radość życia) otrzymało dyplom uznania - oraz w grudniu tegoż roku w Salonie Dorocznym w Towarzystwie Zachęty Sztuk Pięknych w Warszawie ${ }^{52}$. Pierwsza z nich, wysoka na trzy metry „rzeźba Łucznik jako wyraz czujnej, całoprzytomnej świadomości ciała i ducha, natężonych do najwyższego stopnia w ruchu, który wyraził się najsilniej w natężeniu ramion, głowy i szyi [...] dzieło mocne, duże, dynamiczne - jak na rękę kobiecą - bardzo niezwykłe i godne podziwu" 53 , ze względu na swoje rozmiary musiała stanowić swoistą dominantę na wystawie w Muzeum Miejskim ${ }^{54}$. Druga, bardzo pozytywnie oceniana przez

50 Katalog I Wystawy Artystek Polskich, 2-3. Przybyszewski, Olga Niewska, 236-237, w spisie obiektów prezentowanych na I Wystawie Artystek Polskich po weryfikacji danych podaje nieco inne informacje niż widniejące w katalogu (poz. 78: „Łucznik (statuetka) [brąz]”, poz. 79-81: „[fajans]”, poz. 82: „Mascotte’a na radiator [brąz]”); por. MOB, Pierwsza wystawa artystek polskich, teczka 32, Zgłoszenie na wystawę Artystek polskich w Muzeum Miejskim - Olga Niewska - 12 prac; Cennik p. Niewskiej.

51 Z.M., „Rzeźby Olgi Niewskiej w Muzeum Miejskim”, Dziennik Bydgoski, 9 lutego 1930, 12.

52 Przybyszewski, Olga Niewska, 103, 109, 113, 236. Niewska zaproponowała bydgoskiemu muzeum wystawienie rzeźb Łucznik i Przebudzenie obok kilku innych swoich prac, MOB, Pierwsza wystawa artystek polskich, teczka 32, Pismo Olgi Niewskiej do Muzeum Miejskiego w Bydgoszczy, 17 XII 1929 r.

53 Z.M., „Rzeźby Olgi Niewskiej”, 12.

54 MOB, Pierwsza wystawa artystek polskich, teczka 32, Fragment I Wystawy Artystek Polskich, 1930 r. - rzeźba Łucznik, fotografia. 
krytykę rzeźba Przebudzenie (Radość życia) ${ }^{55}$, zachwyciła również autora artykułu w „Dzienniku Bydgoskim”: „Przebudzenie, przedstawione w postaci kobiety wielkości naturalnej w pozie półleżącej, wspartej na rękach, z głową lekko w tył przechyloną, z wyrazem sennego rozmarzenia na twarzy. Tę chwilę i stan psychiczny tak trudny do wyrażenia zapomocą plastyki, oddała artystka znakomicie, przyczem umyślnie nie uwydatniła wyraźnie poszczególnych linij, zwłaszcza kończyn rąk i nóg, niezbudzonych jeszcze zupełnie do życia i ruchu, pogrążonych częściowo w bezruchu, cały zaś nacisk położony jest na linję ogólną i na subtelny wyraz oblicza. Kompozycja ta sprawia bardzo harmonijne i poetyczne wrażenie" ${ }^{56}$. Ta dojrzała rzeźba, będąca swoistą manifestacją uczuć artystki do męża Mieczysławy Ćwiklińskiej, Henryka Madera, z którym później zawarła związek małżeński ${ }^{57}$, została wystawiona także w lipcu i sierpniu 1936 roku na XI Olimpiadzie Sztuki w Berlinie i w maju 1939 roku na wystawie „Świat kobiety” w Resursie Obywatelskiej w Warszawie, potwierdzając tym samym swoją wysoką wartość artystyczną ${ }^{58}$.

Dwie kolejne prace Olgi Niewskiej wymienione w cytowanym katalogu zostały wykonane z brązu jako statuetki-nagrody sportowe. W 1928 roku pokazano je na Wystawie Sportowej (przygotowawczej do Wystawy Olimpijskiej w Amsterdamie) w Salonie Związku Zawodowego Polskich Artystów Plastyków ${ }^{59}$, a za Łuczniczkę (Kobieta strzelająca z łuku, Apoteoza łucznictwa) artystka w tym samym roku otrzymała nagrodę na Olimpijskiej Wystawie Sztuki w Amsterdamie w konkursie rzeźb wykonanych przez kobiety ${ }^{60}$. W lokalnej prasie następująco opisano pierwszą statuetkę: „Wśród tych mniejszych prac najlepiej chyba przedstawia się rzeźba $U$ mety. Znowu moment ruchu, ujęty jak najtrafniej w bronzie, z którym harmonizuje wyraz fizycznego wysiłku, wyrażonego nietylko w całym kształcie biegnącego młodzieńca, ale i w jego niemal natchnionej twarzy, w wyrazie ust" ${ }^{61}$. Statuetka U mety (Szlakiem Kadrówki, Legionista) z 1925 roku stanowiła Nagrodę Marszałka Piłsudskiego dla zwycięzcy Marszu Szlakiem Kadrówki ${ }^{62}$. Drugą pracę z brązu - mierzącą 43 centymetry „Postać klęczącej Łuczniczki [...], która razi trochę przesadnym

\footnotetext{
Przybyszewski, Olga Niewska, 103, 109, 113.

Z.M., „Rzeźby Olgi Niewskiej”, 12.

Przybyszewski, Olga Niewska, 103, 109, 113.

Przybyszewski, Olga Niewska, 238-239.

Przybyszewski, Olga Niewska, 236.

Przybyszewski, Olga Niewska, 94, 98, 236.

Z.M., „Rzeźby Olgi Niewskiej”, 12.

Przybyszewski, Olga Niewska, 91-92.
} 
ruchem szyi” ${ }^{33}$ Niewska zaprojektowała w 1927 roku jako nagrodę w zawodach kobiecych ${ }^{64}$. W zamierzeniu muzeum prezentowane rzeźby sportowe miały zachęcić do odwiedzenia wystawy między innymi członków Bydgoskiego Klubu Sportowego ${ }^{65}$.

$\mathrm{Na}$ uwagę zasługują również kolejne dzieła rzeźbiarki - figurki wykonane $\mathrm{z}$ fajansu (błędnie określone w katalogu wystawy i artykule prasowym jako porcelanowe ${ }^{66}$. Pierwsza z nich, „postać siedzącego Japończyka, oddana z właściwym charakterem" ${ }^{67}$, była prezentowana na przełomie 1921/1922 roku w Salonie Dorocznym w Towarzystwie Zachęty Sztuk Pięknych w Warszawie, w lutym 1923 roku na wystawie rzeźb Olgi Niewskiej w Towarzystwie Zachęty Sztuk Pięknych w Warszawie (wystawa indywidualna), a w styczniu 1924 roku na wystawie rzeźb Olgi Niewskiej oraz malarstwa Henryka Nowiny-Czernego i Józefa Toma w Salonie Czesława Garlińskiego w Warszawie ${ }^{68}$. Ceramiczny Japończyk (Mnich, Uśmiech, Chińczyk), zaprojektowany w 1921 roku, powielany był także w technice malowanego fajansu i brązu' a obecnie jego repliki znajdują się w kilku kolekcjach muzealnych (w Muzeum Narodowym w Warszawie i Muzeum Narodowym w Szczecinie oraz w Muzeum Ziemi Kujawskiej i Dobrzyńskiej we Włocławku), a także w zbiorach prywatnych (w Krakowie i Warszawie) ${ }^{70}$. To dzieło Niewskiej posiada także Muzeum Okręgowe im. Leona Wyczółkowskiego w Bydgoszczy - zostało zakupione (za 200 złotych) 10 kwietnia 1930 roku przez ówczesne Muzeum Miejskie $^{71}$; transakcja ta była pokłosiem współpracy bydgoskiej instytucji

63 Z.M., „Rzeźby Olgi Niewskiej”, 12.

64 Przybyszewski, Olga Niewska, 91.

65 MOB, Pierwsza wystawa artystek polskich, teczka 32, Pismo Muzeum Miejskiego w Bydgoszczy do Bydgoskiego Klubu Sportowego, Bydgoszcz, 25 II 1930 r.

${ }^{66}$ Katalog I Wystawy Artystek Polskich, 2-3; Z.M., „Rzeźby Olgi Niewskiej”, 12; por. Przybyszewski, Olga Niewska, 236-237.

67 Z.M., „Rzeźby Olgi Niewskiej”, 12.

68 Przybyszewski, Olga Niewska, 233-235.

69 Muzeum w Bydgoszczy. Katalog wystawy 26 września - 28 grudnia 2008, red. Barbara Chojnacka, Danuta Sójkowska, i Michał Woźniak (Od Kościoła Klarysek po Wyspę Młyńską. Muzeum w Bydgoszczy 1923-2008, t. 2. red. Michał Woźniak) (Bydgoszcz: Muzeum Okręgowe im. Leona Wyczółkowskiego, 2008), 174; zob. też „Olga Niewska, Japończyk”, DESA Dzieła Sztuki i Antyki, Dostęp 16 czerwca 2018, http://desa.art.pl/index.php?obiekt=2979\&language=en.

70 Kubaszewska i Przybyszewski, „Niewska Olga”, 84; Przybyszewski, Olga Niewska, 25. Repliki „Japończyka” wytwarzały fabryki fajansu w Skawinie i Włocławku, zob. Daranowska-Łukaszewska, „Szczekowska (Niewska-Szczekowska)”.

71 Inwentarz Muzeum Miejskiego w Bydgoszczy i karta naukowa obiektu podają także: „Chińczyk, fajans, odlew, Olga Niewska, zakup z budżetu”; Kubaszewska i Przybyszewski, „Niewska Olga”, 84; Muzeum w Bydgoszczy. Katalog, 174, poz. II.106: „Japończyk (Chińczyk, Uśmiech) 
z rzeźbiarką przy okazji I Wystawy Artystek Polskich ${ }^{72}$. Dwie pozostałe figurki prezentowane w mieście nad Brdą: „melancholijny piesek i królik, które to zwierzęta udały się naszej artystce bardzo dobrze"73, także przyciągają swoim niepowtarzalnym wyglądem. Fajansowy Piesek (Melancholik) z 1923 roku przedstawia buldoga francuskiego ${ }^{74}$.

Zdaniem bydgoskiego publicysty „Świetną również jest mała figurka bronzowa, zwana po francusku mascotte'ą; oddaje ona z przedziwnym efektem wyraz ruchu i pędu, czem spełnia dobrze swoje przeznaczenie jako artystyczna ozdoba samochodów"75. Została ona wystawiona w 1928 roku na wspomnianej już Wystawie Sportowej (przygotowawczej do Wystawy Olimpijskiej w Amsterdamie) w Salonie Związku Zawodowego Polskich Artystów Plastyków $^{76}$. Zachwyt lokalnego krytyka prasowego wzbudził także „puhar [sic] odlany w bronzie, zewnątrz spatynowany, wewnątrz złocony, [...] który uderza pomysłowością kształtu oraz rytmiczną linją postaci, któremi przyozdobiona jest jego powierzchnia"77. Puchar ów, z przeznaczeniem na nagrody - na przykład Nagrodę Prezydenta (Ignacego Mościckiego) w derbach za 1930 rok - powielano niemal masowo ${ }^{78}$. Brązowy był także „medalionik z husarzem, mający w sobie coś z filigranowej roboty mistrzów Odrodzenia”79. Medalion Husarz osadzony na marmurowym postumencie stanowił Nagrodę Prezesa Rady Ministrów RP (Walerego Sławka) w IX Międzynarodowych Zawodach Konnych w 1930 roku $^{80}$. Warto wspomnieć również dwie brązowe plakiety: jedną przedstawiającą Łucznika ${ }^{81}$, drugą zaś „z profilem Piłsudskiego, [która jest] traktowana plastyką szeroką, wymagającą niezwykłej pewności ręki”»2.

Kontakty Olgi Niewskiej z Muzeum Miejskim nie zakończyły się z chwilą zamknięcia wystawy sztuki kobiet i zakupem figurki Japończyka (Chińczyka)

/ proj. Olga Niewska / 1923 (?) / fajans / 27,5 x 24,0 x 20,0 cm / sygn. i dat. wewnątrz, u dołu: OLGA NIEWSKA 1923 (?) (malowanie naszkliwne) / zakup, 1930 / MOB SR-33”.

72 MOB, Pierwsza wystawa artystek polskich, teczka 32, Pismo Muzeum Miejskiego do Olgi Niewskiej w Warszawie, Bydgoszcz 11 III 1930 r.

73 Z.M., „Rzeźby Olgi Niewskiej”, 12.

74 Przybyszewski, Olga Niewska, 179-180, 182.

75 Z.M., „Rzeźby Olgi Niewskiej”, 12.

76 Przybyszewski, Olga Niewska, 236.

77 Z.M., „Rzeźby Olgi Niewskiej”, 12.

78 Przybyszewski, Olga Niewska, 93, 95, 98.

79 Z.M., „Rzeźby Olgi Niewskiej”, 12.

80 Przybyszewski, Olga Niewska, 93.

81 Katalog I Wystawy Artystek Polskich, 2-3.

82 Z.M., „Rzeźby Olgi Niewskiej”, 12. 
(il. 2) do zbiorów bydgoskiej instytucji kultury. Dwa dzieła o największych gabarytach - Łucznik (il. 3) i Przebudzenie (il. 4) - za zgodą artystki były prezentowane w mieście nad Brdą aż do 4 października 1930 roku. Decydenci muzealni, doceniając wartość artystyczną tych prac, chcieli nabyć jedną z nich; do czasu zdobycia funduszy na zakup miały one pozostać w Bydgoszczy ${ }^{83}$. Cena za Łucznika wynosiła piętnaście tysięcy złotych, a za Przebudzenie dwanaście tysięcy złotych, przy czym Niewska w piśmie do Muzeum oświadczyła: „pragnąc jednak umożliwić WPanom nabycie rzeźby mojej, gotowa jestem zaakceptować taką sumę, jaką WPanowie będą mogli na ten cel przeznaczyć. Zaznaczam, że w tym wypadku biorę przedewszystkiem pod uwagę zainteresowanie się WPanów moją pracą, z czego wynika chęć pozostawienia Bydgoszczy trwalszej pamiątki po sobie" ${ }^{84}$. Pomimo dobrych chęci obu stron, dzieła warszawskiej artystki nie udało się zakupić, powodem był brak funduszy wynikający z trudnego położenia finansowego miasta ${ }^{85}$. Rzeźby zostały zapakowane i wysłane do Warszawy w dwóch skrzyniach przez bydgoską firmę C. Hartwig S.A. z siedzibą przy ul. Dworcowej ${ }^{86}$. Po kilku dniach artystka zatelefonowała do muzeum z informacją, że otrzymała niekompletną rzeźbę Łucznika - ponieważ w skrzyni brakowało łuku, prosiła o pisemne zaświadczenie o zapakowaniu tego elementu dzieła ${ }^{87}$. Pismo z zapewnieniem o profesjonalnym owinięciu łuku i przymocowaniu go do dolnej części skrzyni, z dołączonym szczegółowym protokołem przeprowadzonych czynności pakowania, podpisanym przez sekretarza muzealnego Kazimierza Boruckiego i woźnego Nowickiego, niezwłocznie przesłano na adres autorki ${ }^{88}$. Nie natrafiono na dalszą korespondencję dotyczącą zaginionego łuku, można zatem

83 MOB, Pierwsza wystawa artystek polskich, teczka 32, Pismo Muzeum Miejskiego do Olgi Niewskiej w Warszawie, Bydgoszcz 11 III 1930 r.; Pismo Olgi Niewskiej do Muzeum Miejskiego w Bydgoszczy, Warszawa 18 III 1930 r.; Zaświadczenie z dn. 4 X 1930 r.

84 MOB, Pierwsza wystawa artystek polskich, teczka 32, Pismo Olgi Niewskiej do Muzeum Miejskiego w Bydgoszczy, Warszawa 18 III 1930 r.

85 MOB, Pierwsza wystawa artystek polskich, teczka 32, Pismo Olgi Niewskiej do Muzeum Miejskiego w Bydgoszczy, 16 IX 1930 r.; Pismo Muzeum Miejskiego w Bydgoszczy do Olgi Niewskiej w Warszawie, Bydgoszcz, 25 IX 1930 r.

86 MOB, Pierwsza wystawa artystek polskich, teczka 32, Pierwsze pismo do firmy C. Hartwig w Bydgoszczy, 23 IV $1930 \mathrm{r}$.

87 MOB, Pierwsza wystawa artystek polskich, teczka 32, Wzmianka napisana przez Boruckiego, Bydgoszcz, 16 X $1930 \mathrm{r}$.

88 MOB, Pierwsza wystawa artystek polskich, teczka 32, Pismo Muzeum Miejskiego w Bydgoszczy do Olgi Niewskiej w Warszawie, Bydgoszcz, 16 X 1930 r. wraz z Protokołem przy pakowaniu rzeźb Olgi Niewskiej, Bydgoszcz, 4 X 1930 r. 
domniemywać, że fragment Łucznika został odnaleziony w skrzyni przesłanej przez muzeum.

\section{Bydgoskie Popiersie marszałka Józefa Piłsudskiego}

Józef Piłsudski, współtwórca niepodległości Polski, był jednym z najczęściej uwiecznianych bohaterów narodowych. Całe rzesze zawodowych artystów, ale również amatorów, pragnęły wykonać wizerunek tego wybitnego człowieka zarówno za jego życia, jak i - tym bardziej - po śmierci. Powstawały zatem liczne fotografie, obrazy, grafiki i rysunki, w tym karykatury i ekslibrisy, znaczki pocztowe, rzeźby i pomniki, tablice pamiątkowe, medale, monety i banknoty, kartki żywnościowe, aż po tkaniny artystyczne z podobizną Wodza Narodu. Wiele spośród tych przedstawień wykonano na zamówienie władz państwowych i samorządowych, wojska, organizacji patriotycznych i stowarzyszeń w celu upamiętnienia osoby Marszałka. Każda chyba większa miejscowość Drugiej Rzeczypospolitej chlubiła się posiadaniem jego wizerunku ${ }^{89}$. Wśród bydgoszczan - i zasadniczo wśród mieszkańców Wielkopolski - Piłsudski nie cieszył się większą sympatią, przede wszystkim ze względu na jego lewicowe poglądy polityczne i obojętność wobec powstania wielkopolskiego ${ }^{90}$, a w mieście nad Brdą gościł jedynie 6 i 7 czerwca 1921 roku ${ }^{91}$. Jednak również tutaj doczekał się on trzech tablic pamiątkowych (najbardziej okazałą, przekazaną społeczeństwu w 1937 roku, zaprojektował Teodor Gajewski ${ }^{92}$ i najpraw-

89 Szerzej Jan Rećko, Józef Piłsudski w sztuce i upamiętnianiu. Katalog (Bydgoszcz-Lubartów: Polonia Aid Foundation Trust, 2010).

90 W zachodniej Polsce (do 1938 r. Bydgoszcz należała do województwa poznańskiego), gdzie rządziła endecja, utrzymywała się stała niechęć do Piłsudskiego. Zarzucano mu dystans wobec planów przyłączenia ziem zachodnich do II RP, niewielkie wsparcie dla powstania wielkopolskiego 1918/1919 r. oraz powstań śląskich, niedopuszczanie przedstawicieli Poznańskiego do udziału w rządzie polskim, promowanie piłsudczyków, a także konspiracyjną i lewicową przeszłość; szerzej zob. Zbigniew Dworecki, Poznańskie i Piłsudski (Poznań: Wydawnictwo Poznańskie, 2008); zob. też Rajmund Kuczma, „Bydgoskie pomniki, tablice i rzeźby Marszałka Józefa Piłsudskiego w latach 1931-1939”, Kalendarz Bydgoski (1990): 248-249; por. Krzysztof Osiński, „Bydgoszcz w hołdzie Marszałkowi”, Tygodnik Bydgoski, Dostęp 16 czerwca 2018, http://tygodnikbydgoski.pl/historia/bydgoszcz-w-holdzie-marszalkowi.

91 Anna Nadolska, „Pierwszy Marszałek. Wątki bydgoskie”, Kalendarz Bydgoski 52 (2019): 35; Krzysztof Osiński, Bydgoskie puzzle. Szkice z dziejów miasta nad Brdą (Bydgoszcz-Gdańsk: Patria Media, 2018), 77-82; szerzej Krzysztof Rogucki, Józef Piłsudski na Kujawach i Pomorzu (Bydgoszcz: Samorząd Województwa Kujawsko-Pomorskiego, Gmina Miasta Toruń, Urząd Miejski w Kowalewie Pomorskim, 2011), 37-63.

92 Pierwszą tablicę pamiątkową odsłonięto na Dworcu Głównym (1931), drugą na terenie koszar 61. Pułku Piechoty Wielkopolskiej przy ul. Północnej 2-4 (ob. ul. Powstańców War- 
dopodobniej pięciu kameralnych rzeźb umieszczonych we wnętrzach obiektów użyteczności publicznej ${ }^{93}$. Ponadto 15 sierpnia 1931 roku przed głównym wejściem bydgoskiej Szkoły Podchorążych dla Podoficerów przy ul. Gdańskiej $190^{94}$ odsłonięto „nadnaturalnej wielkości” popiersie marszałka Józefa Piłsudskiego, którego autorką była Olga Niewska (il. 5). Stało się to zaledwie półtora roku po prezentacji prac warszawskiej rzeźbiarki w Muzeum Miejskim. Najprawdopodobniej dzieła artystki oglądały wówczas prominentne osobistości z kręgów lokalnej władzy, kultury lub/i wojska, w dodatku Niewska znana była jako rzeźbiarka, dla której pozuje elita sanacyjna. Nie można wykluczyć, że przebywając w Bydgoszczy w 1930 roku artystka nawiązała jakieś kontakty w lokalnym środowisku władzy bądź została polecona bydgoskim wojskowym przez kogoś z miejscowej elity lub ze stolicy ${ }^{95}$.

szawy) (1936), trzecia upamiętniała pobyt Piłsudskiego w 1921 r. w kamienicy ówczesnego prezydenta miasta Jana Maciaszka przy ul. Gdańskiej 92 i tam została umieszczona; tablice zniszczyli Niemcy w 1939 r. Zob. Kuczma, „Bydgoskie pomniki”, 250-251; Kazimierz Borucki, Tablice pamiątkowe Bydgoszczy (Bydgoszcz: Bydgoskie Towarzystwo Naukowe, 1963), 26, 29; Rogucki, Józef Piłsudski na Kujawach, 46-48; Nadolska, „Pierwszy Marszałek”, 37; Bydgoszcz i powiaty: bydgoski, szubiński i wyrzyski. Mała encyklopedia turystyczna, oprac. Wojciech Rzeźniacki (Bydgoszcz: Wydawnictwo Związku Popierania Turystyki, 1938), 239, 262; Rećko, Józef Piłsudski, 50; Krzysztof Rogucki, Józef Piłsudski w Bydgoszczy (Bydgoszcz: RENOMA BIS, 2007), 15. Obecnie trzecia tablica jest odtworzona.

93 Pierwszą rzeźbę umieszczono w ratuszu przy ul. Jezuickiej 1 (1933), drugą w gmachu Państwowego Seminarium Nauczycielskiego Męskiego przy ul. Seminaryjnej 3 (1935), trzecią w auli Miejskiego Liceum i Gimnazjum Męskiego przy ul. Mikołaja Kopernika 1 (1935), czwartą w auli I Państwowego Liceum i Gimnazjum im. Marszałka Józefa Piłsudskiego przy pl. Wolności 9 (1936), piątą w gmachu Szkoły Podchorążych dla Podoficerów przy ul. Gdańskiej 190; wszystkie zniszczyli Niemcy we wrześniu 1939 r. Zob. Kuczma, „Bydgoskie pomniki”, 253-254; Rogucki, Józef Piłsudski na Kujawach, 46. Eugeniusz Gliwiński, „Popiersie Marszałka Józefa Piłsudskiego w Seminarium Nauczycielskim Męskim w Bydgoszczy”, Kalendarz Bydgoski (1993): 198-199, podaje, że popiersie w gmachu przy ul. Seminaryjnej 3 odsłonięto w 1932 r.; por. Osiński, Bydgoskie puzzle, 138-140; Nadolska, „Pierwszy Marszałek”, 37. Obecnie w tym gmachu znajduje się Inspektorat Wsparcia Sił Zbrojnych.

95 Przybyszewski, Olga Niewska, 122; Kazimierz Borucki, Pomniki w Bydgoszczy zniszczone przez okupanta w latach 1939-1945 (Bydgoszcz: Bydgoskie Towarzystwo Naukowe, 1965), 47; „Uroczystości w Szkole Podchorążych”, Dziennik Bydgoski, 18 sierpnia 1931, 2; por. Kuczma, „Bydgoskie pomniki”, 249, który błędnie podaje, że pomnik odsłonięto 14 VIII 1931 r.; Rogucki, Józef Piłsudski na Kujawach, 47; Krzysztof Drozdowski i Anna Kozłowska-Ryś, „Złamana szabla Prezydenta. Mjr Jan Konoplicki - prymus bydgoskiej Oficerskiej Szkoły dla Podoficerów”, W Militaria pomorskie. T. 9, red. Mirosław Giętkowski i Łukasz Nadolski (Bydgoszcz: Muzeum Wojsk Lądowych, 2015), 166-167; Kubaszewska i Przybyszewski, „Niewska Olga”, 85; Daranowska-Łukaszewska, „Szczekowska Olga”, 247; Narodowe Archiwum Cyfrowe, sygn. 1-U-461-1, Odsłonięcie pomnika Marszałka Józefa Piłsudskiego w Bydgoszczy, foto. Witold Pikiel, 1931. Rećko, Józef Piłsudski, 38, podaje błędnie datę odsłonięcia pomnika i fundatora; zob. też Osiński, „Bydgoszcz w hołdzie”; Osiński, Bydgoskie puzzle, 136-137; Nadolska, „Pierwszy Marszałek”, 37. 
W ówczesnej prasie uroczyste odsłonięcie pomnika Marszałka z udziałem władz państwowych i samorządowych, delegacji różnych stowarzyszeń, rodzin wojskowych i zaproszonych gości łączono z obchodami rocznicy „cudu nad Wisłą” i święta żołnierza polskiego, a w szczególności z oficerską promocją wychowanków tutejszej szkoły ${ }^{96}$.Z kolei Krzysztof Rogucki sugeruje, że odbyło się to „dla upamiętnienia wizyty Marszałka” w Bydgoszczy dziesięć lat wcześniej ${ }^{97}$. Pomnik ufundowali uczniowie i absolwenci szkoły ${ }^{98}$, natomiast aktu odsłonięcia dokonał generał dywizji Aleksander Osiński z Warszawy - Inspektor Armii i były inspektor szkolnictwa wojskowego ${ }^{99}$. Na uroczystość przybyła też autorka rzeźby i wraz z grupą dygnitarzy pozowała do pamiątkowej fotografii (il. 6) ${ }^{100}$. Dokumentacja fotograficzna z odsłonięcia bydgoskiego pomnika Piłsudskiego znajduje się w zbiorach Muzeum Narodowego w Warszawie ${ }^{101}$.

W relacji „Dnia Bydgoskiego” stwierdzono: „Pomnik przedstawia się okazale. Na wysokim, ciekawie ujętym cokole, na którym widnieją w kamieniu wyryte słowa: Wodzowi Narodu - Wcieleniu Polski Bohaterskiej Józefowi Piłsudskiemu w hołdzie - Podchorążowie, mieści się brązowe popiersie Marszałka” ${ }^{102}$. Pierwowzorem popiersia była przedstawiająca Piłsudskiego rzeźba, którą Niewska wykonała w 1926 roku, tuż przed przewrotem majowym: do figury ujętej w trzech czwartych, ukazującej mężczyznę w mundurze bez odznak i bez nakrycia głowy, opartego oburącz na szabli, pozował sam Marszałek (il. 7,8$)$. Jest to jedna z najlepszych realizacji rzeźbiarskich warszawskiej

96 „Uroczystości w Szkole Podchorążych”, 2; „Uroczystości w Bydgoszczy”, Światowid, 22 sierpnia 1931, 15; „Odsłonięcie pomnika Marszałka Piłsudskiego w Bydgoszczy”, Ilustrowany Kuryer Codzienny, 19 sierpnia 1931, 3; „Odsłonięcie pierwszego w Bydgoszczy pomnika Marszałka Piłsudskiego”, Dzień Bydgoski. Bezpłatne pismo codzienne, 18 sierpnia 1931, 1; „Podniosła uroczystość promowania na oficerów wychowanków 7 kursu Szkoły Podchorążych w Bydgoszczy”, Dzień Bydgoski. Bezpłatne pismo codzienne, 18 sierpnia 1931, 7; zob. też Przybyszewski, Olga Niewska, 122; Drozdowski i Kozłowska-Ryś, „Złamana szabla”, 166.

97 Rogucki, Józef Piłsudski w Bydgoszczy, 4, 11, 13-14, podaje błędnie, że pomnik Piłsudskiego stanął 23 X $1931 \mathrm{r}$.

98 „Odsłonięcie pomnika Marszałka”, 3; Rogucki, Józef Piłsudski na Kujawach, 47.

99 „gen. Osiński wzniósł okrzyk ku czci Marszałka Piłsudskiego, muzyka odegrała hymn narodowy, oddziały sprezentowały broń, a oczom zgromadzonych ukazało się wykute w bronzie popiersie Marszałka, dłuta panny Olgi Niwskiej” - „Uroczystości w Bydgoszczy”, 15; por. „Odsłonięcie pomnika Marszałka”, 3; „Uroczystości w Szkole Podchorążych”, 2; Rogucki, Józef Piłsudski na Kujawach, 47; Drozdowski i Kozłowska-Ryś, „Złamana szabla”, 166.

${ }^{100}$ Fotografię wykonał Witold Pikiel: MNW, Zbiory Ikonograficzne i Fotograficzne, DI 92431/106; Rzeźba Olgi Niewskiej. Katalog, s. 36.

101 MNW, Zbiory Ikonograficzne i Fotograficzne, DI 92431/104-109; Rzeźba Olgi Niewskiej. Katalog, 34, 36.

102 „Odsłonięcie pierwszego w Bydgoszczy pomnika”, 1. 
artystki ${ }^{103}$. Mocne w wyrazie bydgoskie Popiersie marszałka Józefa Piłsudskiego wzorowane na niemal całopostaciowym przedstawieniu Wodza Narodu nie było jedynym obiektem tego typu. Tożsamy monument autorstwa Niewskiej odsłonięto w Hucie „Pokój” w Nowym Bytomiu na Śląsku w 1937 roku ${ }^{104}$.

Na miesiąc przed odsłonięciem bydgoskiego monumentu do Urzędu Porządku Publicznego Oddział Budowlany przy Magistracie wpłynęło pismo podpułkownika doktora Franciszka Polniaszka ${ }^{105}$, komendanta Szkoły Podchorążych dla Podoficerów, z prośbą o zgodę na budowę pomnika Piłsudskiego, którego opis przedstawił następująco: „Cokół pomnika wyk. z piaskowca wysokości 3,20 m, na którym umieszczone zostanie popiersie Marszałka Polski z bronzu o 0,70 m wysokości” ${ }^{106}$. W kolejnym piśmie komendant przekonywał, że Olga Niewska jest wybitną artystką, a jej prace dobrze znają i cenią

${ }^{103}$ Na zdjęciu przedstawiającym rzeźbę Józef Piłsudski napisał dedykację: „Przemiłej Pani Oldze - wdzięczny manekin”. Rzeźba nie zachowała się. Przybyszewski, Olga Niewska, 79-84, 122; Wojciech Przybyszewski, „Jak Piłsudski ‘za manekin robił' ”, Spotkania z Zabytkami 11 (2001): 25-27. Niewska była ostatnią artystką, której Piłsudski pozował; Komit., „W pracowniach znanych artystek: Olga Niewska”, AS, 25 października 1936, 2; K. Winkler, „Gdy Marszałek pozował do portretu...”, Polska Zbrojna, 2 czerwca 1935, 3; Daranowska-Łukaszewska, „Szczekowska Olga”, 247; Kubaszewska i Przybyszewski, „Niewska Olga”, 85. W 1916 r. w Krakowie Piłsudski pozował do rzeźby Konstantemu Laszczce - późniejszemu mistrzowi Olgi Niewskiej. Nie można wykluczyć, że Laszczka pośredniczył w nawiązaniu kontaktu rzeźbiarki z Marszałkiem, Rećko, Józef Piłsudski, 9; Tomasz Stańczyk, „Rzeźbiarski portret Marszałka”, Dostęp 16 czerwca 2018, http://muzeumpilsudskiblog.pl/rzezbiarski-portret-marszalka/; zob. też „Popiersie Józefa Piłsudskiego”, Connaisseur Kraków, Salon Dzieł Sztuki, Dostęp 15 lipca 2018, http://koneser.krakow.pl/biografie/205-konstanty-laszczka/oferty/3948-popiersie-jozefa-pilsudskiego; „Popiersie Marszałka Józefa Piłsudskiego - kopia”, Wirtualne Muzea Podkarpacia, Dostęp 15 lipca 2018, http://wmp.podkarpackie. pl/2017/01/25/\%EF\%BB\%BFpopiersie-marszalka-jozefa-pilsudskiego-kopia/; „Popiersie Piłsudskiego w Kancelarii Prezydenta”, Kurier 365.pl, Dostęp 15 lipca 2018, https://www. kurier365.pl/polityka-prywatno\%C5\%9Bci/5001-popiersie-pilsudskiego-w-kancelarii-prezydenta.html.

${ }^{104}$ Pomnik nie zachował się, Przybyszewski, Olga Niewska, 122-124; Daranowska-Łukaszewska, „Szczekowska Olga”, 247; Daranowska-Łukaszewska, „Szczekowska (Niewska-Szczekowska)"; Melbechowska-Luty, Posagi i ludzie, 246.

${ }^{105}$ Franciszek Polniaszek - doktor prawa; służył w I Kompanii Kadrowej, a następnie w 5. Pułku Piechoty Legionów; w latach 1927-1931 komendant bydgoskiej Oficerskiej Szkoły dla Podoficerów (przemianowanej na Szkołę Podchorążych dla Podoficerów); z jego w inicjatywy w 1928 r. w szkole powstało muzeum; od 20 VIII 1931 r. dowódca 54. Pułku Piechoty Strzelców Kresowych w Tarnopolu; od 1933 r. działał w tarnopolskim komitecie budowy pomnika Marszałka; ofiara zbrodni katyńskiej w kwietniu 1940 r.

106 Archiwum Państwowe w Bydgoszczy (dalej: APB), Akta miasta Bydgoszczy 1920-1939, 189 (dalej: AmB), sygn. 4325, Prośba o pozwolenie na budowę pomnika Marszałka Józefa Piłsudskiego do Urzędu Porządku Publicznego Oddział Budowlany przy Magistracie z 13 VII 1931 r., s. 1 (do pisma dołączono projekt cokołu); zob. też Krzysztof Drozdowski, Bydgoska architektura militarna w latach 1772-1945, t. 3 (Warszawa: Agencja Wydawnicza CB, 2017), 130. 
wielkopolscy włodarze: wojewoda poznański Roger Adam Raczyński (prezes poznańskiego BBWR) oraz jego zastępca ${ }^{107}$. Niebawem wojewoda poznański, zdając się na opinię konserwatora doktora Nikodema Pajzderskiego, zatwierdził projekt pomnika pod względem artystycznym ${ }^{108}$ i na tej podstawie bydgoski Magistrat zezwolił na budowę monumentu przed szkołą wojenną ${ }^{109}$. Cokół, na którym umieszczono rzeźbiarski portret Marszałka wykonał bydgoski zakład kamieniarsko-rzeźbiarski Jakuba Joba - założony w 1905 roku i od lat trzydziestych XX wieku zajmujący posesję na rogu ulic Dworcowej 102 i Jana III Sobieskiego $2^{110}$.

Warto wspomnieć także o prasowym zawiadomieniu, które pojawiło się w „Dzienniku Bydgoskim” na dwa tygodnie przed odsłonięciem pomnika Piłsudskiego. Anonimowy czytelnik w liście do redakcji informował, że inicjatorem jego budowy nie są wychowankowie Szkoły Podchorążych dla Podoficerów, lecz komendant placówki, który w ten sposób chce uczcić koniec swojej kadencji i wyjazd z Bydgoszczy, natomiast na uczniów została nałożona przymusowa składka w celu sfinansowania monumentu ${ }^{111}$. Komitet budowy pomnika Piłsudskiego dopiero po odbytej uroczystości wystosował do prasy sprostowanie owej wiadomości. Stwierdzono w nim, że wszystkie podane zarzuty są nieprawdziwe, gdyż inicjatywa upamiętnienia Marszałka wyszła od podchorążych najstarszego rocznika piechoty, a poparli ją pozostali uczniowie, którzy ustalili wielkość składki i przedłożyli władzom szkoły projekt pomnika ${ }^{112}$.

107 APB, AmB, sygn. 4325, Pismo w związku z budową pomnika Marszałka Piłsudskiego z 21 VII 1931 r., s. 5 (do pisma dołączono fotografię pomnika Olgi Niewskiej). Artystka zwracała się do wysokich urzędników państwowych z propozycją pozowania i otrzymywała wiele pozytywnych odpowiedzi, Przybyszewski, Olga Niewska, 77-80.

108 APB, AmB, sygn. 4325, Zatwierdzenie projektu pomnika Marszałka Piłsudskiego z 23 VII 1931 r.

109 APB, AmB, sygn. 4325, Zezwolenie budowlane z 27 VII 1931 r.

${ }^{110}$ Kuczma, „Bydgoskie pomniki”, 250; Janusz Umiński, „Job Jakub (Job Giuseppe)”, w Encyklopedia Bydgoszczy, t. 2, red. Włodzimierz Jastrzębski (Bydgoszcz: Towarzystwo Miłośników Miasta Bydgoszczy, 2017), 374-375, podaje, że firma wykonała cokół i cztery bryły „pomnika marszałka Józefa Piłsudskiego (wg projektu artystki rzeźbiarki Olgi Niewskiej z Warszawy), odsłoniętego w 1931 r. przed Szkołą Podchorążych dla Podoficerów”.

111 ski. „W sprawie pomnika marsz. Piłsudskiego w Bydgoszczy”, Dziennik Bydgoski, 1 sierpnia 1931, 8; zob. też Drozdowski, Bydgoska architektura, 130; Krzysztof Drozdowski, „Donos na pomnik Piłsudskiego. 'To była przymusowa składka' ”, Gazeta Wyborcza, Dostęp 16 czerwca 2018, http://bydgoszcz.wyborcza.pl/bydgoszcz/7,48722,23003238,donos-na-pomnik-pilsudskiego-to-byla-przymusowa-skladka.html; Osiński, „Bydgoszcz w hołdzie”; Osiński, Bydgoskie puzzle, 137-138.

112 Maciej Szczepan, „W sprawie budowy pomnika marszałka Piłsudskiego”, Dziennik Bydgoski, 20 sierpnia 1931, 9 . 
W Bydgoszczy dzięki wojskowym miał być odsłonięty jeszcze jeden pomnik Józefa Piłsudskiego autorstwa Olgi Niewskiej. Jednak informacji na temat monumentu ustawionego przed kasynem oficerskim 16. Pułku Ułanów Wielkopolskich przy pl. Poznańskim $9^{113}$, podawanych w regionalnej literaturze ${ }^{114}$, nie potwierdza ani lokalna prasa międzywojenna, ani biografowie warszawskiej artystki. Na razie nie odnaleziono także fotografii przedstawiających pomnik Wodza Narodu na tle budynku mieszczącego kasyno. Bydgoskie publikacje w większości powołują się na wspomnienia Marii Jabłońskiej, które ukazały się w księdze jubileuszowej pułku w 1970 roku. Z relacji Jabłońskiej wynika, że „kasyno oficerskie mieściło się przy pl. Poznańskim w jednopiętrowej willi otoczonej ogrodem, stykającym się ze Wzgórzem Dąbrowskiego. Z frontu, przed głównym wejściem na ujętym w dwustronny zajazd trawniku dominowało z granitowego cokołu bronzowe popiersie Marszałka Piłsudskiego, dłuta rzeźbiarki Olgi Niewskiej, ufundowane staraniem Pułku. Uroczyste odsłonięcie pomnika odbyło się wieczorem 19 marca 1934 r.”115 Popiersie to miało być kopią rzeźby stojącej przed bydgoską szkołą wojenną i zostać usunięte we wrześniu 1939 roku ${ }^{116}$.

\section{Epilog}

Pomnik Piłsudskiego ustawiony przed gmachem szkoły podchorążych, tak jak inne polskie symbole narodowe - w tym związane z osobą Marszałka, został zniszczony po zajęciu Bydgoszczy przez Niemców w 1939 roku ${ }^{117}$. W 2001 roku udało się odtworzyć monument w zmienionej, bardzo uproszczonej formie przed siedzibą Muzeum Tradycji Pomorskiego Okręgu Wojskowego przy ul. Czerkaskiej 2 (obecnie Muzeum Wojsk Lądowych w Bydgoszczy) (il. 9). Jego autorami są bydgoscy rzeźbiarze Marek Guczalski i Adam Jezierzański. Niestety nowy pomnik w niczym nie przypomina dzieła Olgi Niewskiej: „około

113 Obecnie w tym budynku mieści się Żłobek Publiczny „Słoneczko”.

114 Drozdowski, Bydgoska architektura, 179; Rogucki, Józef Piłsudski na Kujawach, 47; Kuczma, „Bydgoskie pomniki”, 250; Osiński, „Bydgoszcz w hołdzie”; Osiński, Bydgoskie puzzle, 139; Nadolska, „Pierwszy Marszałek”, 37.

115 Maria Jabłońska, „Pułk w Garnizonie”, w 50-lecie 16 Pułku Ułanów Wielkopolskich im. gen. dyw. Gustawa Orlicz-Dreszera 29.XII.1918-29.XII.1968. red. Maria Jabłońska, i Henryk Kowalski (Bydgoszcz-Londyn: Koło 16 Pułku Ułanów Wielkopolskich, 1970, wyd. II uzupełnione), 179.

${ }^{116}$ Jeśli kopia taka powstała, to Niewska o tym najpewniej nie wiedziała, Osiński, „Bydgoszcz w hołdzie".

${ }^{117}$ Kuczma, „Bydgoskie tablice”, 250; Rogucki, Józef Piłsudski na Kujawach, 48; Osiński, „Bydgoszcz w hołdzie". 
metrową płaskorzeźbę przestawiającą popiersie wielkiego Polaka umieszczono na przedniej ścianie kilkumetrowego cokołu, pod orłem z koroną, który stanął na jego szczycie”. Jedynie napis na ścianie monumentu nawiązuje do oryginału: „Pomnik Marszałka Józefa Piłsudskiego wzniesiony na terenie bydgoskiej Szkoły Podchorążych w 1931 r. Zniszczony przez okupanta w 1939 r. Rekonstruowany przez Towarzystwo Przyjaciół Muzeum POW w 2001 r." ${ }^{118}$ Natomiast z okazji setnej rocznicy odzyskania przez Polskę niepodległości w przeddzień święta narodowego, 10 listopada 2018 roku w pierwotnym miejscu, czyli przed dawnym gmachem Szkoły Podchorążych dla Podoficerów (obecną siedzibą Inspektoratu Wsparcia Sił Zbrojnych) przy ul. Gdańskiej, odsłonięto kopię popiersia Marszałka Piłsudskiego autorstwa Olgi Niewskiej. Nowy monument, wykonany przez Gracjana Kaję, również nie jest wierną rekonstrukcją dzieła rzeźbiarki ${ }^{119}$ - brązowe popiersie jedynie przypomina pracę dłuta Niewskiej, ponieważ zmieniono nieco rysy twarzy Marszałka. W odróżnieniu od pierwotnej wersji, na kamiennym, czarnym cokole, „napisy wykonano z pojedynczych liter w kolorze grafitowym" ${ }^{120}$. Dodatkowo bryła cokołu została znacznie uproszczona, pozbawiona okazałej, rozbudowanej podstawy (il. 10).

Warto również wspomnieć o innej próbie przypomnienia bydgoskiego dzieła Olgi Niewskiej. W listopadzie 2017 roku Muzeum Okręgowe im. Leona Wyczółkowskiego przygotowało wystawę posterową „Józef Piłsudski a Bydgoszcz”, dzięki której bydgoszczanie mogli zapoznać się zarówno z fotografią rzeźbiarskiego popiersia autorstwa Niewskiej z 1931 roku, jak i rekonstrukcją pomnika z początku XXI wieku'121.

${ }^{118}$ Rogucki, Józef Piłsudski na Kujawach, 49; „W Bydgoszczy odsłonięto pomnik Piłsudskiego”, Gazeta Wyborcza, Dostęp 16 czerwca 2018, http://bydgoszcz.wyborcza.pl/bydgoszcz/1,35590, 534999.html; zob. też Nadolska, „Pierwszy Marszałek”, 38; Drozdowski, „Donos na pomnik”.

119 Redaktor, „Piłsudski wrócił do Bydgoszczy”, Dostęp 12 listopada 2018, http://tygodnikbydgoski.pl/wydarzenia/pilsudski-wrocil-do-bydgoszczy-10-11-18; „Pomnik Piłsudskiego stanie przy ul. Gdańskiej. To już pewne”, Gazeta Wyborcza, Dostęp 16 czerwca 2018, http:// bydgoszcz.wyborcza.pl/bydgoszcz/7,48722,22981614,pomnik-pilsudskiego-stanie-przy-ul-gdanskiej-to-juz-pewne.html; „W tym samym miejscu co przed wojną pomnik Piłsudskiego nie stanie”, Bydgoszcz24.pl, Dostęp 16 czerwca 2018, http://bydgoszcz24.pl/pl/11_wiadomosci/18005_w_tym_samym_miejscu_co_przed_wojna_pomnik_pilsudskiego_nie_stanie.html.

120 (ech), „Pomnik Marszałka Józefa Piłsudskiego wrócił do Bydgoszczy”, Dostęp 12 listopada 2018, https://bydgoszcz24.pl/pl/11_wiadomosci/19364_pomnik_marsza_ka_j_zefa_pi_sudskiego_wr_ci_do_bydgoszczy.html; zob. też: Osiński, Bydgoskie puzzle, 141.

${ }^{121}$ Autorzy wystawy: kustosz Anna Nadolska i adiunkt Dariusz Leśniewski, opracowanie graficzne: Ewa Widacka-Matoszko, zob. „Józef Piłsudski a Bydgoszcz - wystawa posterowa”, Dostęp 28 lipca 2018, http://muzeum.bydgoszcz.pl/wystawy/id,244,0,0,Jozef-Pilsudski-a-Bydgoszcz-wystawa-posterowa; Nadolska, „Pierwszy Marszałek”, 38. 


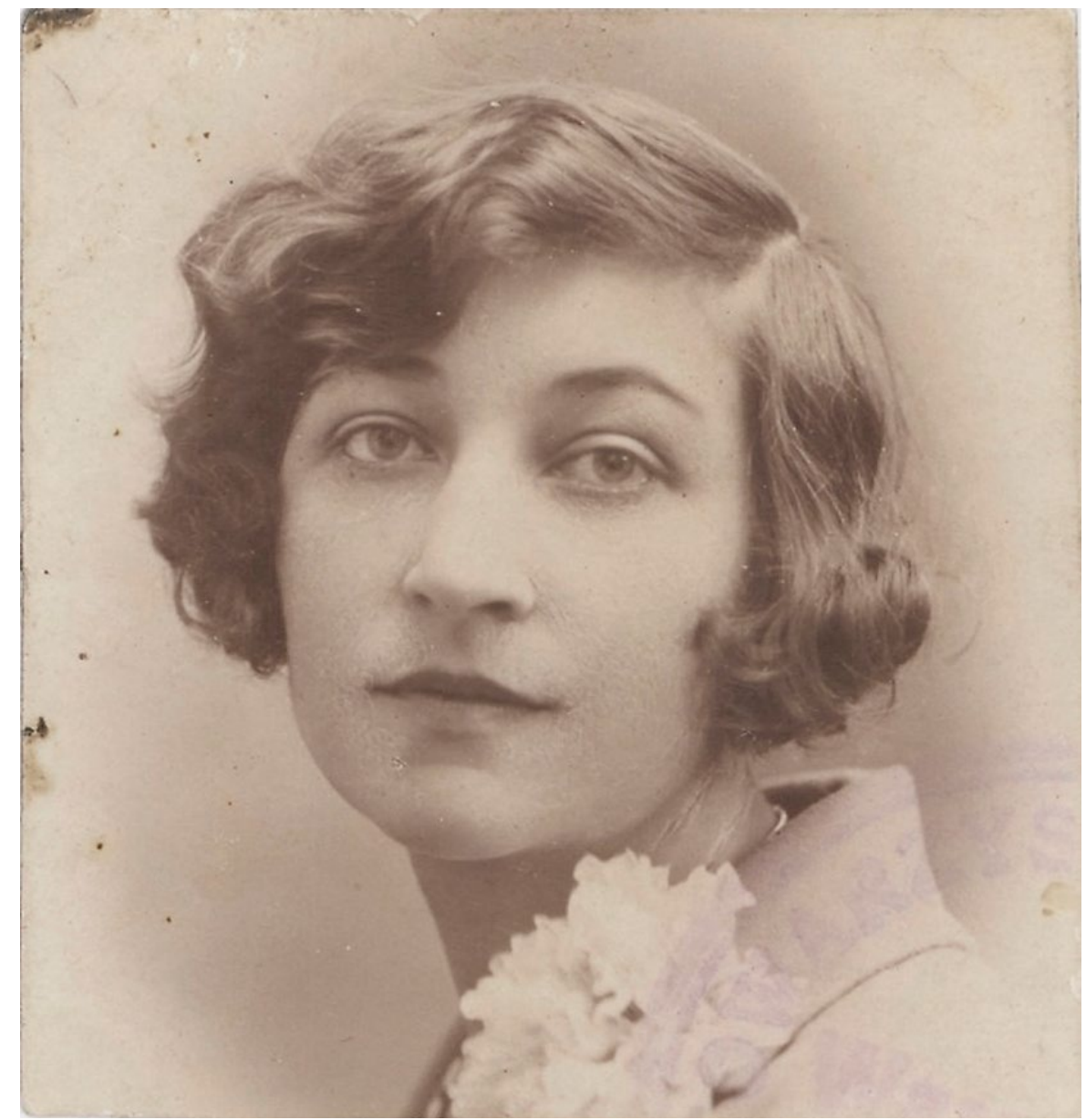

Il. 1. Portret Olgi Niewskiej, ok. 1920 r. Fot. ze zbiorów Muzeum Narodowego w Warszawie (dalej: MNW), sygn. DI 92431/241 


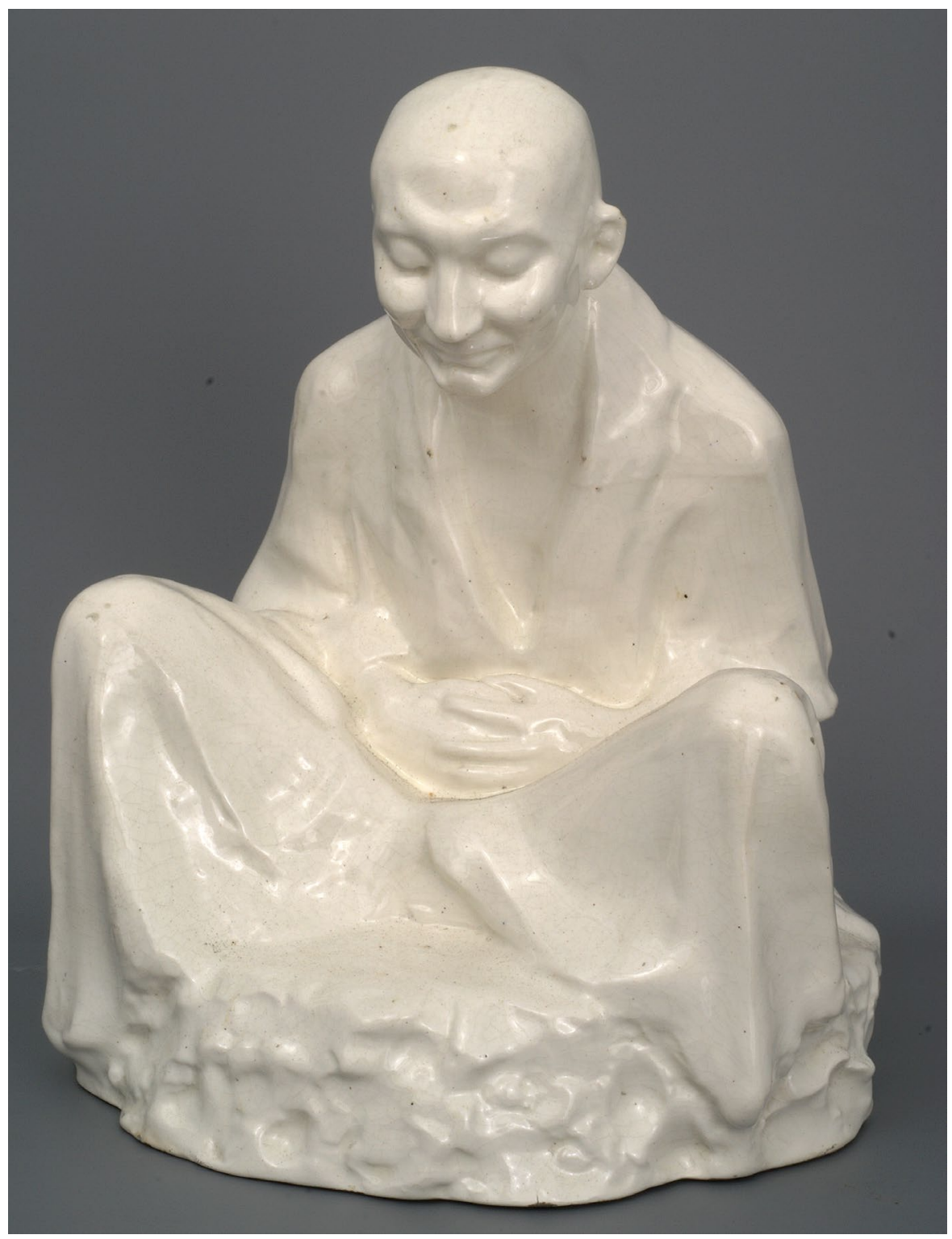

Il. 2. Olga Niewska, Japończyk (Uśmiech), fajans, 1923 (?). Fot. ze zbiorów Muzeum Okręgowego im. Leona Wyczółkowskiego w Bydgoszczy (dalej: MOB), sygn. SR-33, fot. W. Woźniak 


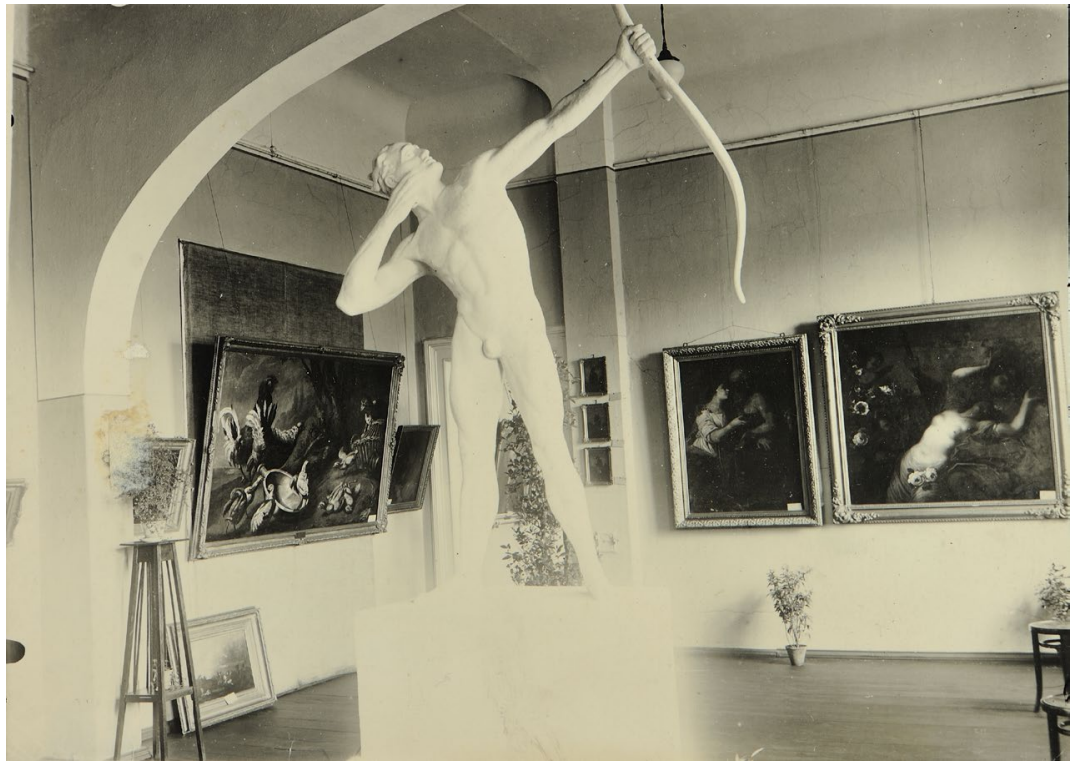

Il. 3. Olga Niewska, Łucznik, gips, 1930. Fot. z archiwum MOB, teczka nr 32, repr. fot. W. Woźniak

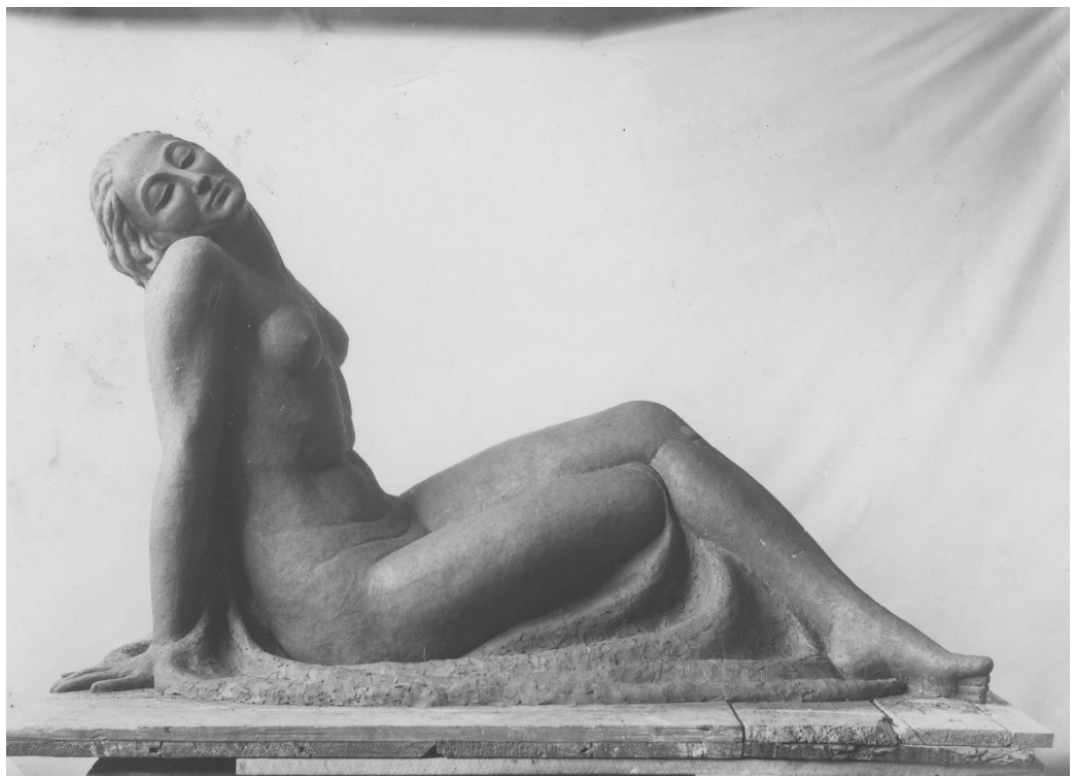

Il. 4. Olga Niewska, Przebudzenie, gips, 1929. Fot. ze zbiorów Narodowego Archiwum Cyfrowego, sygn. 1-K-4424 


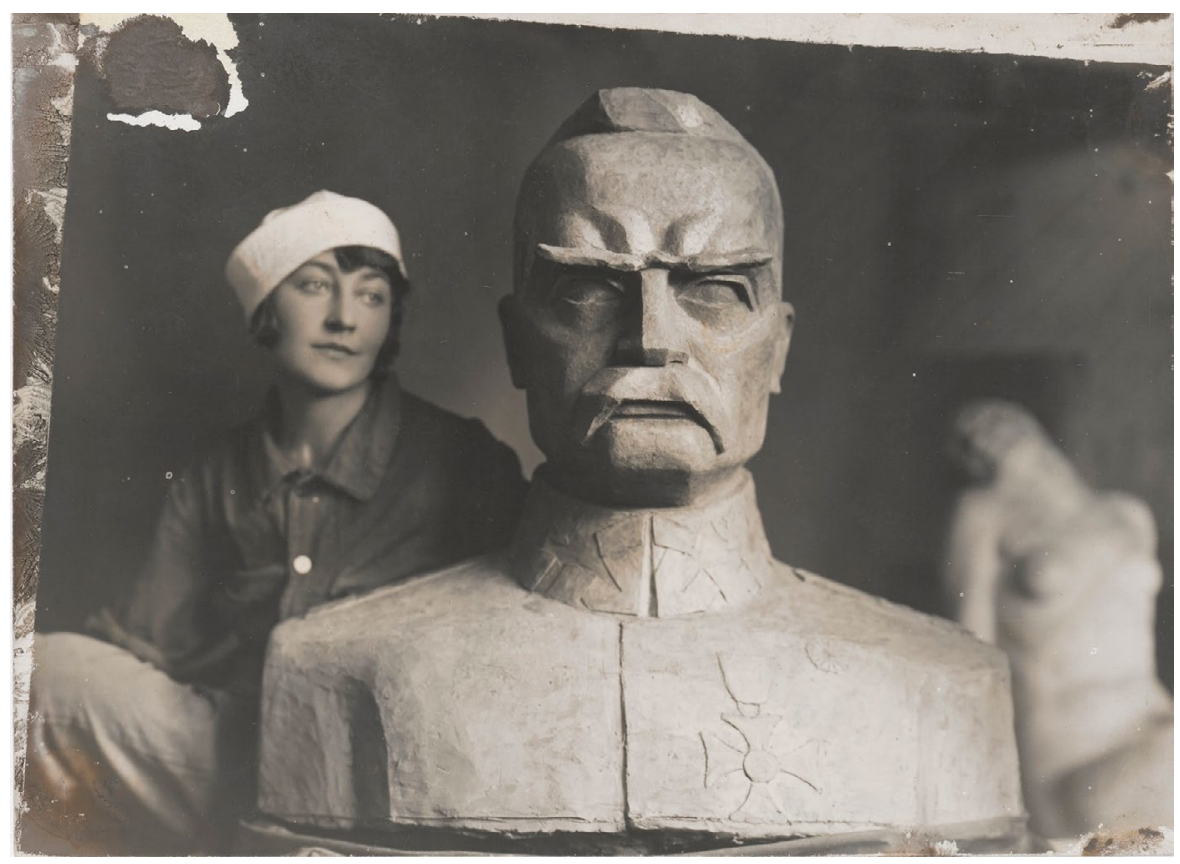

Il. 5. Olga Niewska w swojej pracowni przy ul. Zakroczymskiej w Warszawie, obok popiersie marszałka J. Piłsudskiego, ok. 1930/1931 r. Fot. ze zbiorów MNW, sygn. DI 92431/90 


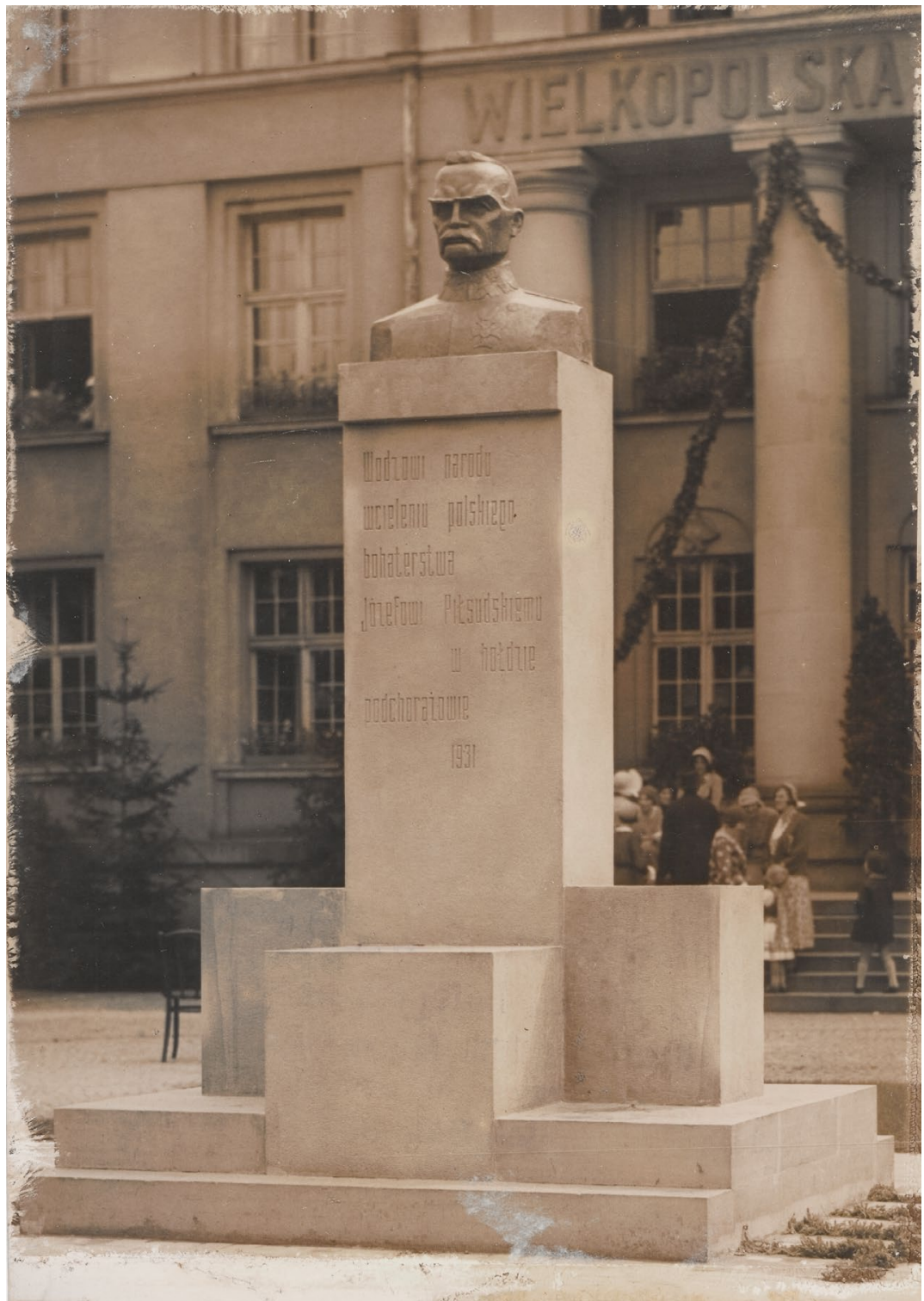

Il. 6. Pomnik marszałka Józefa Piłsudskiego (popiersie autorstwa Olgi Niewskiej) przed Szkołą Podchorążych dla Podoficerów, Bydgoszcz, 15 VIII 1931 r. Fot. ze zbiorów MNW, sygn. DI 92431/107, fot. W. Pikiel 


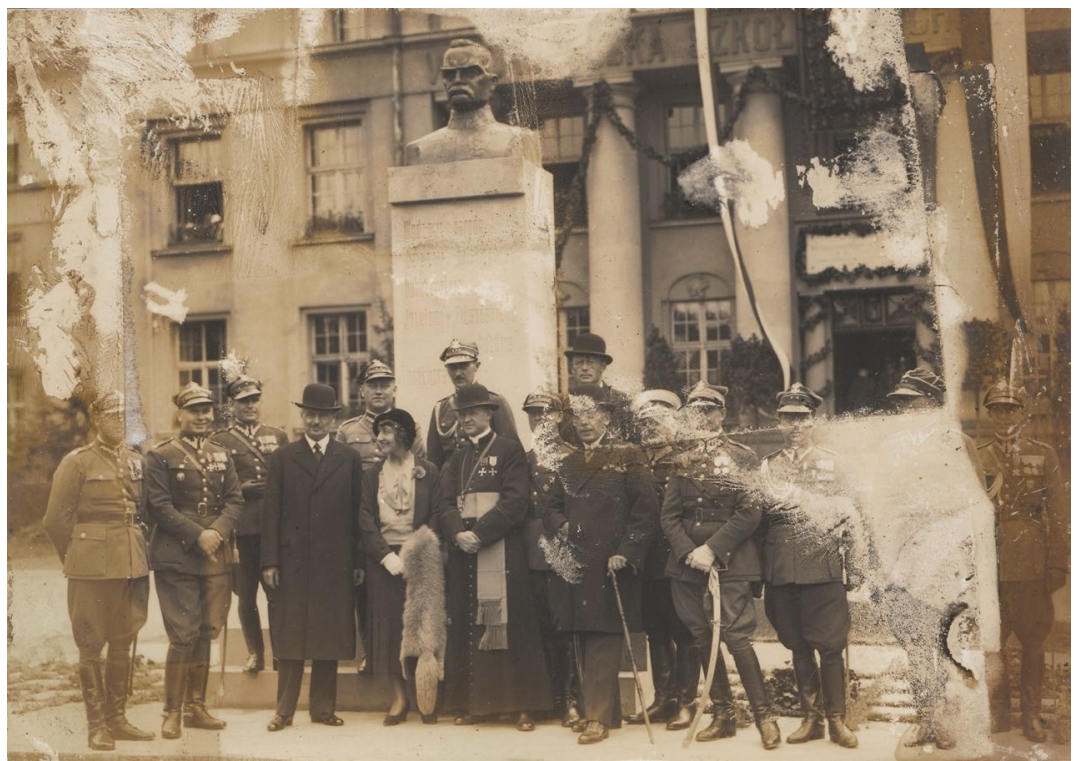

Il. 7. Uroczystość odsłonięcia pomnika marszałka Józefa Piłsudskiego przed Szkołą Podchorążych dla Podoficerów, Bydgoszcz, 15 VIII 1931 r. Olga Niewska, autorka rzeźby, z grupą dygnitarzy. Fot. ze zbiorów MNW, sygn. DI 92431/106, fot. W. Pikiel

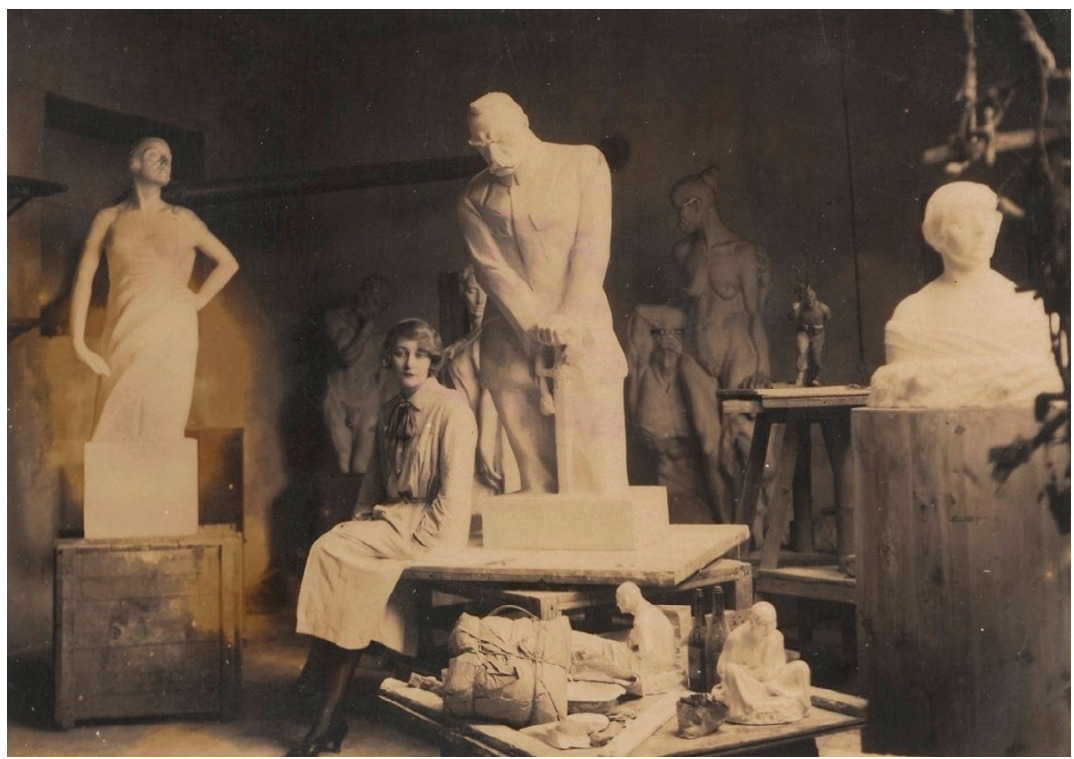

Il. 8. Olga Niewska w swojej pracowni przy ul. Zakroczymskiej w Warszawie, obok posąg marszałka Józefa Piłsudskiego, ok. 1926 r. Fot. ze zbiorów MNW, sygn. DI 92431/82 


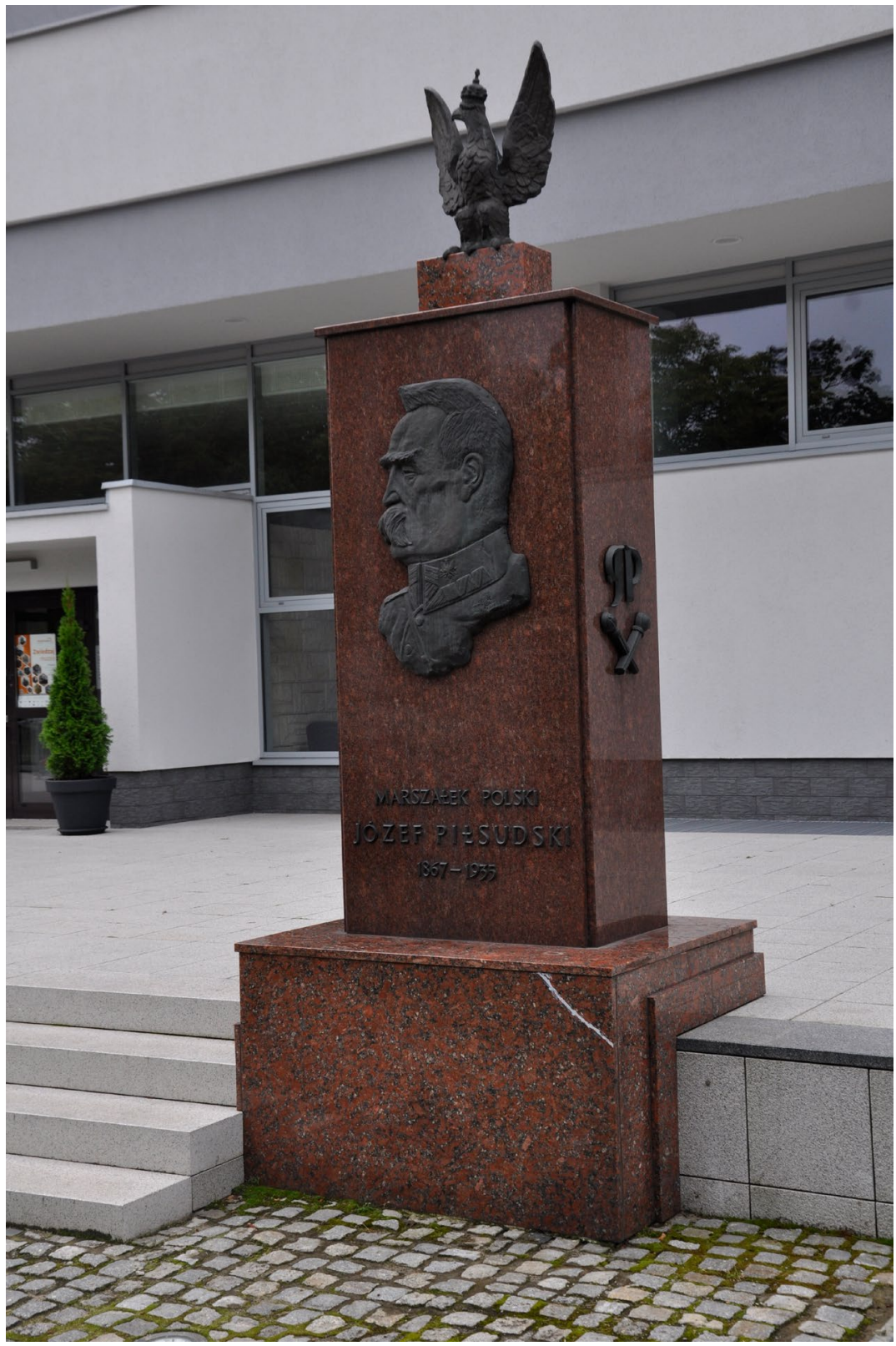

Il. 9. Pomnik marszałka Józefa Piłsudskiego przed Muzeum Wojsk Lądowych w Bydgoszczy, 2017. Fot. Ł. M. Nadolski 


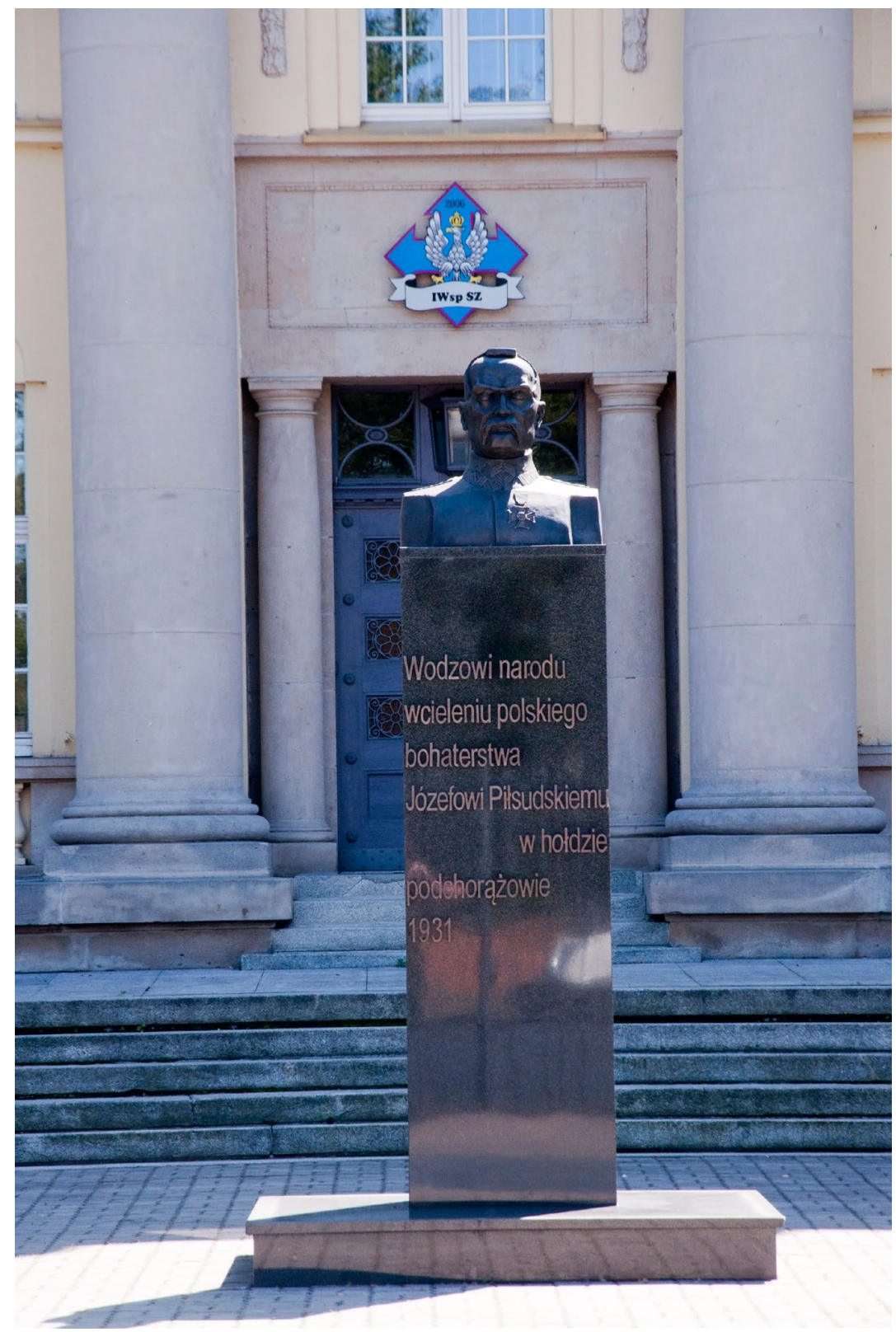

Il. 10. Pomnik marszałka Józefa Piłsudskiego przed Inspektoratem Wsparcia Sił Zbrojnych, Bydgoszcz, 2020. Fot. Ł. M. Nadolski 


\section{Bibliografia}

\section{Źródła archiwalne}

Archiwum Państwowe w Bydgoszczy, Akta miasta Bydgoszczy 1920-1939, 189: sygn. 4325.

Muzeum Narodowe w Warszawie, Zbiory Ikonograficzne i Fotograficzne: rkps 2193/1-3, DI 92431/104-109.

Muzeum Okręgowe im. Leona Wyczółkowskiego w Bydgoszczy: Inwentarz Muzeum Miejskiego w Bydgoszczy, Wykaz teczek z wystawami, poz. 32, Pierwsza wystawa artystek polskich, teczka 32.

Narodowe Archiwum Cyfrowe: sygn. 1-U-461-1, Odsłonięcie pomnika Marszałka Józefa Piłsudskiego w Bydgoszczy, foto. Witold Pikiel, 1931.

\section{Literatura}

Artystki polskie. Katalog wystawy. Red. Agnieszka Morawińska. Warszawa: Muzeum Narodowe, 1991.

Borucki, Kazimierz. Pomniki w Bydgoszczy zniszczone przez okupanta w latach 1939-1945. Bydgoszcz: Bydgoskie Towarzystwo Naukowe, 1965.

Borucki, Kazimierz. Tablice pamiątkowe Bydgoszczy. Bydgoszcz: Bydgoskie Towarzystwo Naukowe, 1963.

Bydgoszcz i powiaty: bydgoski, szubiński i wyrzyski. Mała encyklopedia turystyczna. Opracowanie Wojciech Rzeźniacki. Bydgoszcz: Wydawnictwo Związku Popierania Turystyki, 1938.

Daranowska-Łukaszewska, Joanna. „Szczekowska Olga”. W Polski słownik biograficzny. T. 47 (Szaniawski Józef - Szeliga Franciszek), red. Andrzej Romanowski, 247-250. Warszawa-Kraków: Wydawnictwo Towarzystwa Naukowego Societas Vistulana, 2010-2011.

Drozdowski, Krzysztof. Bydgoska architektura militarna w latach 1772-1945 (seria Fortyfikacje i Budowle Militarne, t. 3). Warszawa: Agencja Wydawnicza CB, 2017.

Drozdowski, Krzysztof, i Anna Kozłowska-Ryś. „Złamana szabla Prezydenta. Mjr Jan Konoplicki - prymus bydgoskiej Oficerskiej Szkoły dla Podoficerów”. W Militaria pomorskie. T. 9, red. Mirosław Giętkowski i Łukasz Nadolski, 161-178. Bydgoszcz: Muzeum Wojsk Lądowych, 2015.

Dworecki, Zbigniew. Poznańskie i Piłsudski. Poznań: Wydawnictwo Poznańskie, 2008.

Dział Sztuki: Powszechna Wystawa Krajowa. Poznań: Powszechna Wystawa Krajowa, 1929.

Gliwiński, Eugeniusz. „Popiersie Marszałka Józefa Piłsudskiego w Seminarium Nauczycielskim Męskim w Bydgoszczy”. Kalendarz Bydgoski (1993): 198-199.

„Historia wystaw sztuki kobiet w Polsce”. Red. Agata Jakubowska. Sztuka i Dokumentacja 15 (2016). 
Hojka, Zdzisław. Muzeum w Bydgoszczy 1923-2008. Dzieje i zbiory (Od Kościoła Klarysek po Wyspę Młyńską. Muzeum w Bydgoszczy 1923-2008. T. 1 red. Michał Woźniak). Bydgoszcz: Muzeum Okręgowe im. Leona Wyczółkowskiego, 2008.

Jabłońska, Maria. „Pułk w Garnizonie”. W 50-lecie 16 Pułku Ułanów Wielkopolskich im. gen. dyw. Gustawa Orlicz-Dreszera 29.XII.1918-29.XII.1968, red. Maria Jabłońska, i Henryk Kowalski, 179-181. Bydgoszcz-Londyn: Koło 16 Pułku Ułanów Wielkopolskich, 1970 (wyd. II uzupełnione).

Katalog I Wystawy Artystek Polskich styczeń-luty 1930. Bydgoszcz: Muzeum Miejskie, 1930.

Kotkowska-Bareja, Hanna. „Olga Niewska”. W Artystki polskie. Katalog wystawy, red. Agnieszka Morawińska, 259. Warszawa: Muzeum Narodowe, 1991.

Kubaszewska, Hanna, i Wojciech Przybyszewski. „Niewska Olga”. W Słownik artystów polskich i obcych $w$ Polsce działajacych (zmarłych przed 1966 r.). Malarze, rzeźbiarze, graficy. T. $6 N-P c$, red. Katarzyna Mikocka-Rachubowa i Małgorzata Biernacka, 84-87. Warszawa: Instytut Sztuki PAN, 1998.

Kuczma, Rajmund. „Bydgoskie pomniki, tablice i rzeźby Marszałka Józefa Piłsudskiego w latach 1931-1939”. Kalendarz Bydgoski (1990): 248-254.

Kunert, Andrzej Krzysztof. „Szczekowski Władysław”. W Polski słownik biograficzny. T. 47 (Szaniawski Józef - Szeliga Franciszek), red. Andrzej Romanowski, 250-252. Warszawa-Kraków: Wydawnictwo Towarzystwa Naukowego Societas Vistulana, 2010-2011.

Melbechowska-Luty, Aleksandra. Posagi i ludzie. Rzeźba polska dwudziestolecia międzywojennego (1918-1939). Warszawa: Wydawnictwo Neriton, 2005.

Morawińska, Agnieszka. „Artystki polskie”. W Artystki polskie. Katalog wystawy, red. Agnieszka Morawińska, 9-16. Warszawa: Muzeum Narodowe, 1991.

Mościcka, Izabela. „Trzy gracje polskiej rzeźby art déco: Gross, Mickun, Niewska”. W Polskie art déco: Materiały piątej sesji naukowej „Polskie art déco. Rzeźba i płaskorzeźba" pod przewodnictwem prof. Ireny Huml, prof. Anny Sieradzkiej i prof. Andrzeja K. Olszewskiego w Muzeum Mazowieckim w Płocku 22-23 kwietnia 2013 roku, red. Zbigniew Chlewiński, 129-141. Płock: Muzeum Mazowieckie, 2015.

Mrozek, Zdzisław. „Polska kultura i sztuka w Bydgoszczy w latach 1920-1939”. W Historia Bydgoszczy. T. 2 cz. 1 1920-1939, red. Marian Biskup, 719-781. Bydgoszcz: Bydgoskie Towarzystwo Naukowe, 1999.

Muzeum w Bydgoszczy. Katalog wystawy 26 września - 28 grudnia 2008, red. Barbara Chojnacka, Danuta Sójkowska, i Michał Woźniak (Od Kościoła Klarysek po Wyspę Młyńską. Muzeum w Bydgoszczy 1923-2008. T. 2 red. Michał Woźniak). Bydgoszcz: Muzeum Okręgowe im. Leona Wyczółkowskiego, 2008.

Nadolska, Anna. „Pierwszy Marszałek. Wątki bydgoskie”. Kalendarz Bydgoski 52 (2019): 35-38.

Osiński, Krzysztof. Bydgoskie puzzle. Szkice z dziejów miasta nad Brdą. BydgoszczGdańsk: Patria Media, 2018. 
Polskie życie artystyczne w latach 1915-1939. Red. Aleksander Wojciechowski. WrocławWarszawa-Kraków-Gdańsk: Ossolineum, 1974.

Porada, Zbigniew. „Polskie artystki w Olimpijskich Konkursach Sztuki i Literatury 1928-1948”. Prace Naukowe Akademii im. Jana Długosza w Częstochowie. Kultura Fizyczna 16, nr 4 (2017): 27-53.

Przybyszewski, Wojciech. „Jak Piłsudski ‘za manekin robił’ ”. Spotkania z Zabytkami 11 (2001): 25-27.

Przybyszewski, Wojciech. Olga Niewska. Piękno za kurtyną zapomnienia. Poznań: Dom Wydawniczy Rebis, 2001.

Rećko, Jan. Józef Piłsudski w sztuce i upamiętnianiu. Katalog. Bydgoszcz-Lubartów: Polonia Aid Foundation Trust, 2010.

Rogucki, Krzysztof. Józef Piłsudski na Kujawach i Pomorzu. Bydgoszcz: Samorząd Województwa Kujawsko-Pomorskiego, Gmina Miasta Toruń, Urząd Miejski w Kowalewie Pomorskim, 2011.

Rogucki, Krzysztof. Józef Piłsudski w Bydgoszczy. Bydgoszcz: RENOMA BIS, 2007.

Rzeźba Olgi Niewskiej. Katalog wystawy. Opracowanie Krystyna Mart. Chełm: Muzeum Chełmskie, czerwiec-październik 2000.

Sosnowska, Joanna. Poza kanonem. Sztuka polskich artystek 1880-1939. Warszawa: Instytut Sztuki PAN, 2003.

Sztuka i Dokumentacja 15 (zeszyt monograficzny: „Historia wystaw sztuki kobiet w Polsce”. Red. Agata Jakubowska) (2016).

Umiński, Janusz. „Job Jakub (Job Giuseppe)”. W Encyklopedia Bydgoszczy. T. 2 red. Włodzimierz Jastrzębski, 374-375. Bydgoszcz: Towarzystwo Miłośników Miasta Bydgoszczy, 2017.

Wystawa „Świat Kobiety” 25.V.-25.VI.1939. Warszawa: Wydawnictwo W. Majchert i Syn, 1939.

\section{Artykuły prasowe}

Komit. „W pracowniach znanych artystek: Olga Niewska”. AS, 25 października 1936, 2. „Kronika. Wystawa artystek polskich”. Dziennik Bydgoski, 26 stycznia 1930, 12.

„Odsłonięcie pierwszego w Bydgoszczy pomnika Marszałka Piłsudskiego”. Dzień Bydgoski. Bezpłatne pismo codzienne, 18 sierpnia 1931, 1.

„Odsłonięcie pomnika Marszałka Piłsudskiego w Bydgoszczy”. Ilustrowany Kuryer Codzienny, 19 sierpnia 1931, 3.

„Podniosła uroczystość promowania na oficerów wychowanków 7 kursu Szkoły Podchorążych w Bydgoszczy”. Dzień Bydgoski. Bezpłatne pismo codzienne, 18 sierpnia 1931, 7.

ski. „W sprawie pomnika marsz. Piłsudskiego w Bydgoszczy”. Dziennik Bydgoski, 1 sierpnia $1931,8$. 
Szczepan, Maciej. „W sprawie budowy pomnika marszałka Piłsudskiego”. Dziennik Bydgoski, 20 sierpnia 1931, 9.

„Uroczystości w Bydgoszczy”. Światowid, 22 sierpnia 1931, 15.

„Uroczystości w Szkole Podchorążych”. Dziennik Bydgoski, 18 sierpnia 1931, 2.

Winkler, K. „Gdy Marszałek pozował do portretu...” Polska Zbrojna, 2 czerwca 1935, 3.

„Wystawa Artystek Polskich”. Gazeta Bydgoska. Kurjer Bydgoski, 26 stycznia 1930, 6.

„Wystawa malarek i rzeźbiarek”. Gazeta Bydgoska. Kurjer Bydgoski, 28 stycznia 1930, 5.

Z.M. „Rzeźby Olgi Niewskiej w Muzeum Miejskim”. Dziennik Bydgoski, 9 lutego 1930, 12.

\section{Netografia}

Balutowska, Katarzyna. „Emancypacja kobiet w sztuce Olgi Niewskiej”. Dostęp 16 czerwca 2018. https://www.polishmuseumofamerica.org/emancypacja-kobiet-w-sztuce-olgi-niewskiej/.

Daranowska-Łukaszewska, Joanna. „Szczekowska (Niewska-Szczekowska) 1. v. Zbiza, 2. v. Maderowa, Olga (1898-1943), rzeźbiarka”. Dostęp 18 grudnia 2017. www.ipsb. nina.gov.pl/a/biografia/olga-szczekowska.

Drozdowski, Krzysztof. „Donos na pomnik Piłsudskiego. ‘To była przymusowa składka’ ”. Gazeta Wyborcza. Dostęp 16 czerwca 2018.

http://bydgoszcz.wyborcza.pl/bydgoszcz/7,48722,23003238,donos-na-pomnik-pilsudskiego-to-byla-przymusowa-skladka.html.

(ech). „Pomnik Marszałka Józefa Piłsudskiego wrócił do Bydgoszczy”. Dostęp 12 listopada 2018. https://bydgoszcz24.pl/pl/11_wiadomosci/19364_pomnik_marsza_ka_j_ zefa_pi_sudskiego_wr_ci_do_bydgoszczy.html.

Freus, Paweł. „Olga Niewska”. CULTURE.PL Twórcy. Dostęp 16 czerwca 2018. http:// culture.pl/pl/tworca/olga-niewska.

„Józef Piłsudski a Bydgoszcz - wystawa posterowa”. Dostęp 28 lipca 2018. http://muzeum.bydgoszcz.pl/wystawy/id,244,0,0,Jozef-Pilsudski-a-Bydgoszcz---wystawa-posterowa.

„Olga Niewska 1898-1943”. Centrum Rzeźby Polskiej w Orońsku. Dostęp 16 czerwca 2018. www.rzezba-oronsko.pl/index.php?kolekcja_crp,38,174,niewska_olga.

„Olga Niewska, Japończyk”. DESA Dzieła Sztuki i Antyki. Dostęp 16 czerwca 2018. http://desa.art.pl/index.php?obiekt=2979\&language=en.

Osiński, Krzysztof. „Bydgoszcz w hołdzie Marszałkowi”. Tygodnik Bydgoski. Dostęp 16 czerwca 2018. http://tygodnikbydgoski.pl/historia/bydgoszcz-w-holdzie-marszalkowi.

„Pomnik Piłsudskiego stanie przy ul. Gdańskiej. To już pewne”. Gazeta Wyborcza. Dostęp 16 czerwca 2018. http://bydgoszcz.wyborcza.pl/bydgoszcz/7,48722,22981614,pomnik-pilsudskiego-stanie-przy-ul-gdanskiej-to-juz-pewne.html. 
„Popiersie Józefa Piłsudskiego”. Connaisseur Kraków, Salon Dzieł Sztuki. Dostęp 15 lipca 2018. http://koneser.krakow.pl/biografie/205-konstanty-laszczka/oferty/3948-popiersie-jozefa-pilsudskiego.

„Popiersie Marszałka Józefa Piłsudskiego - kopia”. Wirtualne Muzea Podkarpacia. Dostęp 15 lipca

2018. http://wmp.podkarpackie.pl/2017/01/25/\%EF\%BB\%BFpopiersie-marszalka-jozefa-pilsudskiego-kopia/.

„Popiersie Piłsudskiego w Kancelarii Prezydenta”. Kurier 365.pl Dostęp 15 lipca 2018. https://www.kurier365.pl/polityka-prywatno\%C5\%9Bci/5001-popiersie-pilsudskiego-w-kancelarii-prezydenta.html.

Redaktor. „Piłsudski wrócił do Bydgoszczy”. Dostęp 12 listopada 2018. http://tygodnikbydgoski.pl/wydarzenia/pilsudski-wrocil-do-bydgoszczy-10-11-18.

Stańczyk, Tomasz. „Rzeźbiarski portret Marszałka”. Dostęp 16 czerwca 2018. http:// muzeumpilsudskiblog.pl/rzezbiarski-portret-marszalka/.

„W Bydgoszczy odsłonięto pomnik Piłsudskiego”. Gazeta Wyborcza. Dostęp 16 czerwca 2018. http://bydgoszcz.wyborcza.pl/bydgoszcz/1,35590,534999.html.

„W tym samym miejscu co przed wojną pomnik Piłsudskiego nie stanie”. Bydgoszcz24. pl Dostęp 16 czerwca 2018. http://bydgoszcz24.pl/pl/11_wiadomosci/18005_w_tym_ samym_miejscu_co_przed_wojna_pomnik_pilsudskiego_nie_stanie.html.

„Wystawa: I Wystawa Artystek Polskich, Wystawy Sztuki Kobiet”. Dostęp 16 czerwca 2018. http://wystawykobiet.amu.edu.pl/wystawa/i-wystawa-artystek-polskich,33. html.

„Wystawy Sztuki Kobiet”. Dostęp 29 czerwca 2018. http://wystawykobiet.amu.edu.pl/ wystawy.html

„Wystawa: Świat Kobiety”. Dostęp 22 lipca 2018. http://wystawykobiet.amu.edu.pl/ wystawa/swiat-kobiety,46.html. 